\title{
LONG-TERM CHANGES IN PRECIPITATION AND TEMPERATURE PATTERNS AND THEIR POSSIBLE IMPACTS ON VEGETATION (TOLFA-CERITE AREA, CENTRAL ITALY)
}

\author{
Savo, V. ${ }^{1 *}$ - De Zuliani, E. ${ }^{1,2}-$ Salvati, L. ${ }^{3}$ - Perini, L. ${ }^{4}$ - CAneva, G. ${ }^{1}$ \\ ${ }^{1}$ Environmental Biology Department, University Roma Tre, Viale Marconi 446, \\ I-00146, Rome, Italy (phone: + 39-06.57336374, fax: +39-06.57336321) \\ ${ }^{2}$ Macchiotonda Natural Reserve, Castello di Santa Severa, I-00058, Santa Marinella, Italy \\ ${ }^{3}$ Council for Research in Agriculture, Centre for the Study of Soil-Plant Relationships (CRA- \\ RPS), Via della Navicella 2-4, I-00184 Rome, Italy \\ ${ }^{4}$ Agricultural Research Council, Unit of Climatology and Meteorology applied to Agriculture \\ (CRA-CMA), Via del Caravita 7a, I-00186, Rome, Italy \\ *Corresponding author \\ e-mail:vsavo@uniroma3.it
}

(Received $8^{\text {th }}$ February 2012; accepted $17^{\text {th }}$ February 2012)

\begin{abstract}
Climate change is a major global issue that impacts vegetation, agriculture, biodiversity and human safety. These impacts are predicted to be intense in the Mediterranean region. The aim of this paper is to define how local climatic trends are affecting plant communities in the Tolfa-Cerite area (Northern Latium), which is a semi-coastal area with Mediterranean to broad-leaf vegetation. Climate data analysis covered a long time period (1951-2007), considering 18 gauging stations. Data were analyzed using geostatistical methods and descriptive statistics. Climate trends and drought indicators, in relation to different vegetation associations, were analyzed using the zonal statistic tool (ArcGIS). During the investigated period, rainfall showed a uniform decreasing trend, while temperature increased, with an irregular trend. The specialization of climatic data showed a shift towards a thermo-Mediterranean bioclimate. Local climatic trends showed to have more severe impacts on specific plant communities (mesophilous forests, endangered shrubland-pastures, relict associations of meadows, etc). The observed trends towards aridity occurred in many areas covered by vulnerable plant communities. Considering the predicted changes in climate conditions for the Mediterranean area, these communities will face a further aridity increase. A permanent monitoring of these communities may increase the effectiveness of conservation policies and sustainable regional planning.
\end{abstract}

Keywords: Bioclimate analysis, climate change, Mediterranean plant communities, Italy

\section{Introduction}

Climate change is currently a major global concern since it could have heavy impacts on living beings, including humans (e.g., Thomas et al., 2004; Hoffman et al., 2009; Fiorillo and McCarthy, 2010). Projected impacts encompass a broad range of effects: the evolution of new plant associations (Jackson and Overpeck, 2000), shifts in the spatial distribution of tree species (e.g., Iverson and Prasad, 1998; Tchebakova et al., 2005; Téllez-Valdéz et al., 2006), animal and insect population decline or shifts (Parmesan et al., 1999; Gibbons et al., 2000; Bombi et al., 2009), reduced food availability and loss in agricultural yield (Ciais et al., 2003; Mendelsohn and Dinar, 2003; Eiji Maeda et al., 2010; Tirado et al., 2010). Many studies (Melillo et al., 1995; Bachelet et al., 2001; Hansen et al., 2001; Shafer et al., 2001; Neilson et al., 2005) agree 
in predicting widespread disruption of native ecosystems caused by the change in climate (see IPCC, 2000) being portrayed by General Circulation Models (GCM) for the near future (Crookston et al., 2010).

The Mediterranean regions are transitional climate regions where it has been hypothesized that climate changes may have pronounced effects (Lavorel et al., 1998; De Luis et al., 2001; Giorgi, 2006; Giorgi and Lionello, 2008). In general, the Mediterranean climate is characterized by cool, wet Winter and hot, dry Summer (Giacobbe, 1964; Henderson-Sellers and Robinson, 1991). The study of several GCM simulations shows a robust picture of climate change over the Mediterranean basin, consisting of a long-term downward trend in rainfall amount (Maheras, 1988; Kutiel et al., 1996; Palutikof et al., 1996; Esteban-Parra et al., 1998; Osborne et al., 2000; IPCC, 2007; Giorgi and Lionello, 2008) and temperature warming (Kutiel and Maheras, 1998; IPCC, 2007) especially in the hot season. Finally, it has been well documented that climate change "will lead to effects such as changes in frequencies of extreme weather events" (IPCC, 2007). An increase in the seasonal variability of climate has also been predicted. However, the Mediterranean basin is characterized by a great variability of climate types (Lionello et al., 2006) and mesoscale features. These features determine climatic gradients within a region, driven by the effects of mountains, valleys and local winds (Somot et al., 2008).

Moreover, climate change in synergy with desertification processes (Puigdefabregas and Mendizabal, 1998; De Luis et al., 2001; Sivakumar, 2007; Salvati et al., 2008), soil erosion (Favis-Mortlock and Savabi, 1996; Williams et al., 1996; Favis-Mortlock and Guerra, 1999; Nearing, 2001; Pruski and Nearing, 2002; Nearing et al., 2005) and land degradation (Attorre et al., 2007) may affect, to different extents, vegetation (e.g., Sabatè et al., 2002; Walther, 2003; Piovesan et al., 2008, Jump and Penuelas, 2005; Jiao et al., 2009).

Bioclimatology is an ecological science dealing with the relations between climate and the distribution of living species, which define specific bioclimatic regions (Rivas Martinez, 1993; Rivas Martinez, 1996). Bioclimatic indicators are based on formulas that measure climatic factors and conditions that may positively/negatively affect vegetation and may correlate to the main type of vegetation of an area. The Tolfa-Cerite area is a coastal and semi-coastal area in Central Italy, where it has previously been hypothesized a transitional shift from a defined Mediterranean to a Temperate bioclimate (Blasi et al., 1999). Thus, vegetation of this area is likely to be sensitive in relation to a shift in climate patterns, since it is already on the boundary between two bioclimatic areas.

Hence, the objective of this paper is to analyze and integrate geostatistical methods and a bioclimatic approach to quantify the effects of recent climate variations on actual vegetation. The aims of this paper are to (i) describe the bioclimate and define the climate trends within a sensitive study area through geostatistical analyses, and (ii) relate these trends to vegetation defining which are the plant communities that will experience the greatest change in climate conditions. This analysis may be useful to define which are the most vulnerable plant communities in the area in prediction of the projected climate changes for the Mediterranean basin. 


\section{Methods}

Methodology for the analysis of climate and vegetation data is detailed in separate paragraphs.

\section{Study area}

The investigated area is located in the Rome prefecture (Latium, central Italy) and covers a total surface area of $556 \mathrm{Km}^{2}$ (Fig. 1). The area is delimited between longitude $11^{\circ} 44^{\prime}-12^{\circ} 11^{\prime}$ and latitude $41^{\circ} 55^{\prime}-42^{\circ} 14^{\prime}$ and it is bounded by the Tyrrhenian Sea on the West, by the Monti Sabatini on the East, and the Monti Cimini and the Mignone river on the North. The area is characterized by lowlands, hills and low mountains (the highest peak of Tolfa Mountains is the Monte delle Grazie, $616 \mathrm{~m}$ ), which constitute a single morphological element, but are defined by different geological features. Some mountains are of volcanic origin, others are formed by older sedimentary deposits of flyschoid origin (Devoto and Lombardi, 1977; Contoli et al., 1980; Angelelli and Faramondi, 1995; Lombardi, 2000). The Southern sector, along the coastline, is typified by more recent geological formations with marine and fluvial sediments.

The typical landscape is characterized by dispersed towns and villages, a mosaic of pastures, cultivated land and woodlands. This landscape has been modified by a millenarian human activity: the area is inhabited since the end of the Bronze Age $\left(9^{\text {th }}-8^{\text {th }}\right.$ centuries B.C.) (Mandolesi, 1999) and there are several archeological settlements and historical monuments.

The $60 \%$ of the total surface of the study area is covered by woodland and seminatural vegetation (Blasi, 2010). In the lower belt, vegetation is mainly Mediterranean with forests dominated by Quercus ilex L. and plant communities of the Quercetea ilicis. However, the $47 \%$ of woodlands is composed by broad-leaf species (especially on the hilly belt): Fagus sylvatica L., Quercus cerris L., Carpinus betulus L., Ostrya carpinifolia Scop. and Castanea sativa Miller (Anzalone, 1961; Spada, 1977; Di Pietro, 2010). Atypical plant communities consist of prairies of Sulfur springs, low belt beech forests and uncommon pastures communities (e.g., Cynaro-Cichorietum pumili) (Fanelli et al., 2007). The area includes many sites of the Natura 2000 network [the Tolfa hilly area is a SPA (Special Protection Area) (Council Directive 79/409/CEE)].

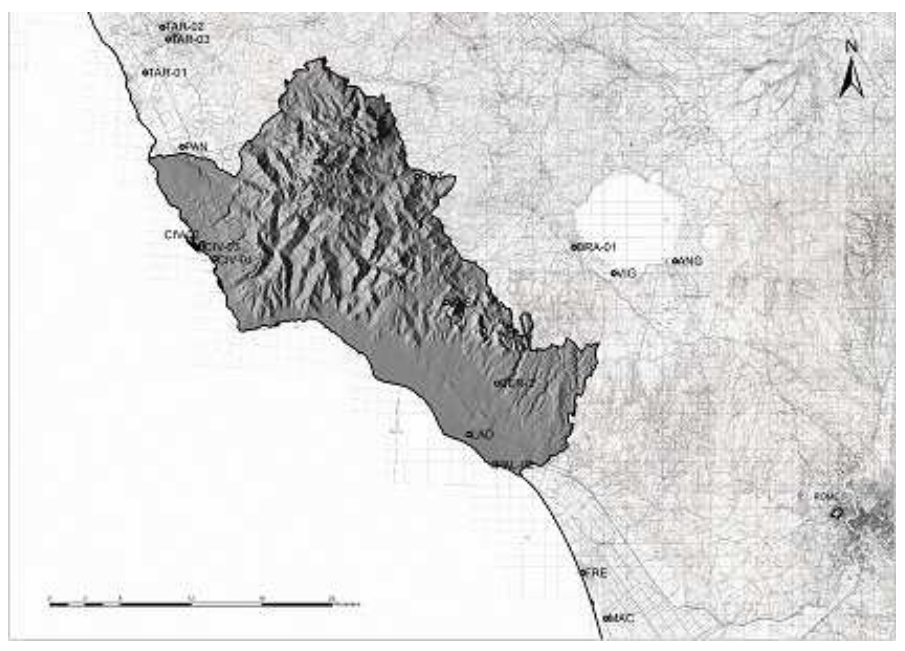

Figure 1. Geographical position of the considered gauging stations within and nearby the study area 


\section{Climate data}

Climate stations within $30 \mathrm{~km}$ of the research area, encompassing the broadest possible elevation range, were selected to capture the variation of the region (altitude and distance from the sea).

Climate data were obtained from the CRA-CMA (Consiglio per la Ricerca e la Sperimentazione in Agricoltura - Unità di Ricerca per la Climatologia e la Meteorologia applicate all'Agricoltura) for the period 1951-2007. Stations with limited years of registration were not considered. As regards the selected stations, years with lacking periods of registration were eliminated from the pool of data.

At the end of this initial screening, we analyzed data registered at six thermopluviometric gauging stations (Allumiere, Bracciano 1, Cerveteri 2, Civitavecchia 1, Maccarese, Tarquinia 1), seven pluviometric gauging stations (Anguillara Sabazia, Fregene, Ladispoli, Pantano Tarquinia, Rota, Sasso Furbara, Tarquinia 2) and five gauging stations with only temperature data (Civitavecchia 2, Civitavecchia 3, Palo Laziale 2, Tarquinia Portaccia, Vigna di Valle). Gauging stations with rainfall data are 13, with temperature data are 11. During the period 1951-1980 some of the gauging stations were inactive (three for rainfall and four for temperature). However, we statistically interpolated the missing values for temperature (see below). Nine stations are within the study area while nine are nearby (Fig. 1).

\section{Climate indicators}

For each station, the average was calculated of the monthly and annual values of maximum, minimum and medium temperature of monthly and annual amounts of rainfall. Higher and lower values of both temperature and rainfall were calculated. Trends in temperature and in rainfall were also calculated on a seasonal basis.

Bioclimatic indexes allow synthesizing complex relations among different sets of climatic data (Blasi, 1996). The following bioclimatic indexes were calculated: Bagnouls-Gaussen Aridity Index (BGI) (Bagnouls and Gaussen, 1953); Mitrakos indexes, for cold and drought stresses (YCS, WCS, YDS, SDS) (Mitrakos, 1980); Emberger rainfall index (Q) (Emberger, 1955); De Martonne aridity index (De Martonne, 1926); Rivas Martinez indexes (It, Ic, IO, Ios2, Ios3, Ios4) for defining the bioclimatic areas (Rivas Martinez, 1993; Rivas Martinez, 1996; Rivas Martinez and Loidi Arregui, 1999). The moving average of temperature and rainfall was also calculated, considering a window range of ten years for the whole study period (19512007). The outputs of these analyses were used to create graphs and spotlight trends in variations of rainfall and temperature regimes and to define the most likely period of shifting of climate conditions.

Temperature and rainfall data were then analyzed parting data in two periods (19511980 and 1978-2007), considering the 1980s as a break point, to highlight the variability pattern and trends in their distribution (Giavante et al., 2009). For each station, the averages of monthly and yearly rainfall and temperature values were calculated considering the two new periods and then compared, reporting any monthly, seasonal and annual variation. Bioclimatic indexes were elaborated for these new periods as well. Three gauging stations (Cerveteri 2, Tarquinia 1, and Fregene) were not used in this comparison as regards the rainfall data since data were missing for one of the two periods. Temperature data were lacking at Cerveteri 2, Palo Laziale 2, Tarquinia 1, and Tarquinia Portaccia for the period (1951-1980). These missing data were interpolated 
using a simple linear regression method (Goovaerts, 2000). Rainfall is a parameter with a nonlinear distribution, with random variations that could seldom be inferred. Temperature, on the other hand, has more regular trends in a small area and is mainly affected by elevation.

Geostatistical methods were used to interpolate the spatial correlation between neighboring observations to predict attribute values at unsampled locations in relation to the distance and similarity of close stations (Ordinary Kriging - Tabios and Salas, 1985; Phillips et al., 1992; Goovaerts, 2000; Attorre et al., 2007). Rainfall and temperature data were regionalized using a standardized Ordinary Kriging interpolation method (Benavides et al., 2007) using the Spatial Analyst tool in ArcGis 10.0 (ESRI, Redlands, CA, 2006).

Climatic maps for the two periods were produced in relation of several climate parameters (Annual mean of medium temperature, annual mean precipitation, mean of minimum temperature of January and February; mean of maximum temperature of July and August; mean precipitation of October, November, December and July). A standard error prediction map was produced to estimate the precision of the spatialization process for each map (Hartkamp et al., 1999). Afterward, the raster files contained in the ordinary kriging maps of the annual mean of medium temperature, the maps of annual mean precipitation and the maps of the BGI index were used to obtain three new derived maps. Values of the datasets of the period 1978-2007 were subtracted from the values of the period 1951-1978 using the ArcGIS tool "raster calculator" (in numerical values), obtaining the following maps:

(i) map of the variation of the annual mean precipitation (difference between the total amounts);

(ii) map of the variation of the annual mean of medium temperature (difference between the two values);

(iii) map of the difference of BGI values.

\section{Vegetation and climate analysis}

The vegetation map of the Rome Province (Fanelli et al., 2007) was uploaded in ArcGIS. This map has a scale of 1: 25.000 and it depicts the real vegetation areas detailing the plant community syntaxa. Each polygon is characterized by a vegetation type. However, since some vegetation categories were describing very similar plant communities, these polygons were re-categorized in more comprehensive categories. Then, the raster files (and related layers) of the three above mentioned (i-iii) maps where overlaid to the vegetation map using ArcGIS.

The "zonal statistic" tool provided by ArcGIS was used to define the variation of precipitation, temperature and BGI index values for each vegetation category and each polygon, considering minimum, maximum and the average values. Polygons defined by the same vegetation category have a diverse distribution in relation to climate patterns.

\section{Results}

Results on climate analysis are showed in summary paragraphs. The analysis of climate change in relation to vegetation data are reported subsequently. 


\section{Rainfall distribution}

The Ordinary Kriging map of annual mean precipitation is reported in Fig. 2 along with the related standard error prediction map. It is possible to define an increasing gradient of rainfall amount from the coast to the uplands.
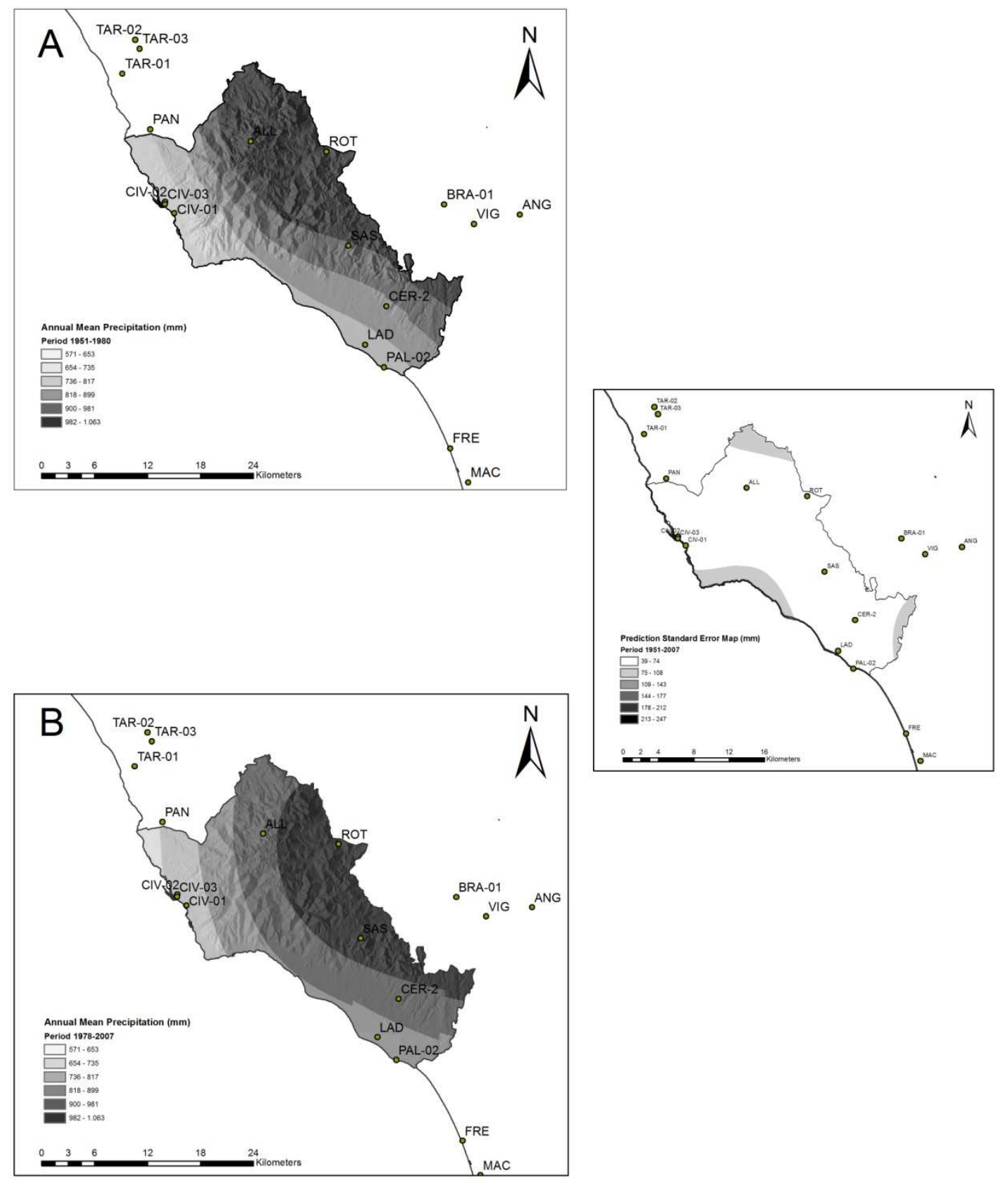

Figure 2. Ordinary Kriging spatialization of annual mean precipitation (in $\mathrm{mm}$ ) considering the periods 1951-1980 (a) and 1978-2007 (b) and standard error map related to the whole period

During 1951-1980 (Table 1) the rainiest month was November, while the driest month was July. The highest value of annual rainfall $(1117.8 \mathrm{~mm})$ was registered at Rota (191 m above sea level); only at four gauging stations the average annual rainfall 
is higher than $1000 \mathrm{~mm}$. The highest value $(166.5 \mathrm{~mm})$ of monthly rainfall was registered at Bracciano 1 (228 $\mathrm{m}$ above sea level). The lowest value of annual rainfall $(670.4 \mathrm{~mm})$ was registered at Tarquinia 2 (14 $\mathrm{m}$ above sea level, a.s.1.). The lowest value of monthly rainfall $(7.8 \mathrm{~mm})$ was registered at Ladispoli ( $5 \mathrm{~m}$ a.s.l.) in July.

During 1978-2007 (Table 1) the rainiest month was October while the driest month was July. The highest value of annual rainfall $(998.3 \mathrm{~mm})$ was registered at Bracciano 1; at all the gauging stations the average annual rainfall was less than $1000 \mathrm{~mm}$. The highest value (155.4 mm) of monthly rainfall was registered at Anguillara Sabazia (160 $\mathrm{m}$ a.s.1.) in October. The lowest value of annual rainfall $(569.0 \mathrm{~mm})$ was registered at Civitavecchia 1 (5 $\mathrm{m}$ a.s.l.). The lowest value of monthly rainfall $(10.0 \mathrm{~mm})$ was registered at Ladispoli (5 $\mathrm{m}$ a.s.1.) in July.

In Fig. 2 it is showed the Ordinary Kriging map of Annual mean precipitation (in $\mathrm{mm}$ ) of the two considered periods (1951-1980; Fig. 2a-1978-2007; Fig. 2b). The decrease of rainfall is evident for the whole area, and especially for the hilly areas. In the study area, a decrease of annual rainfall in nine out of 10 stations was observed ranging from $18.5 \%(81.5 \mathrm{~mm})$ at Maccarese to $4.4 \%(29.3 \mathrm{~mm})$ at Tarquinia 2 . A slight $(1.1 \mathrm{~mm}, 0.1 \%)$ increase in annual rainfall amount was observed only in Sasso Furbara, an upland and wooded area. A reduction in rainfall was also highlighted on a seasonal basis. The decrease, considering the rainfall amount, was maximum during Autumn, a typical wet season in the Mediterranean region. The highest decrease in annual rainfall, considering the absolute value in $\mathrm{mm}$, was calculated for the Rota station, with an estimated reduction of $203.8 \mathrm{~mm}$ (18.2\% of the total).

The moving average of the annual rainfall, calculated for pluviometric stations, also highlighted a decreasing trend (an example is provided in Fig. 3). 
Table 1. Average monthly and annual values of precipitation (in $\mathrm{mm}$ ) for the two periods (1951-1980 and 1978-2007). The variation in rainfall was calculated subtracting the more recent period to the first one. The rainiest months are in bold, the driest months in italic

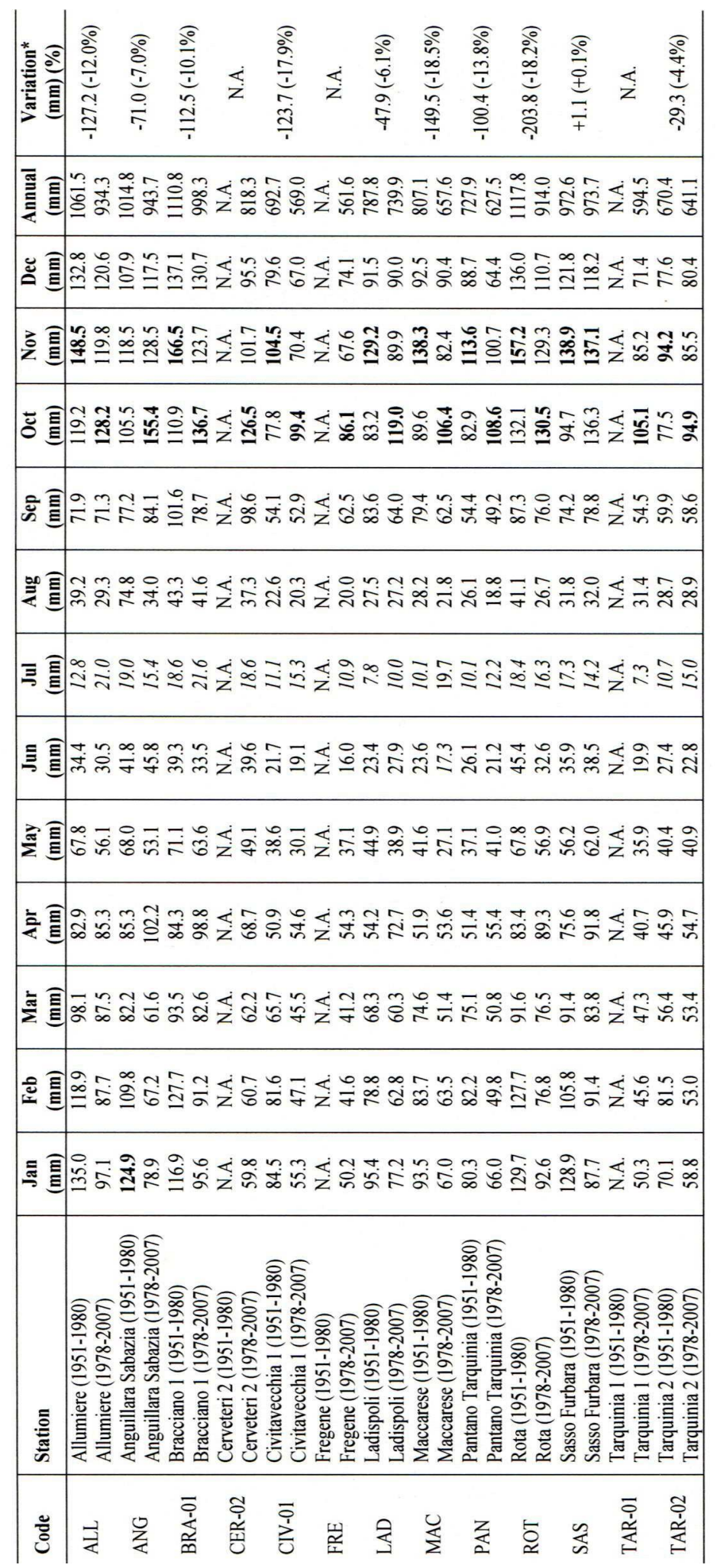

*Variation in Annual Rainfall was obtained subtracting the Average Annual Rainfall of the period 1978-2007 to the Average Annual Rainfall of the period 1951-1980. 


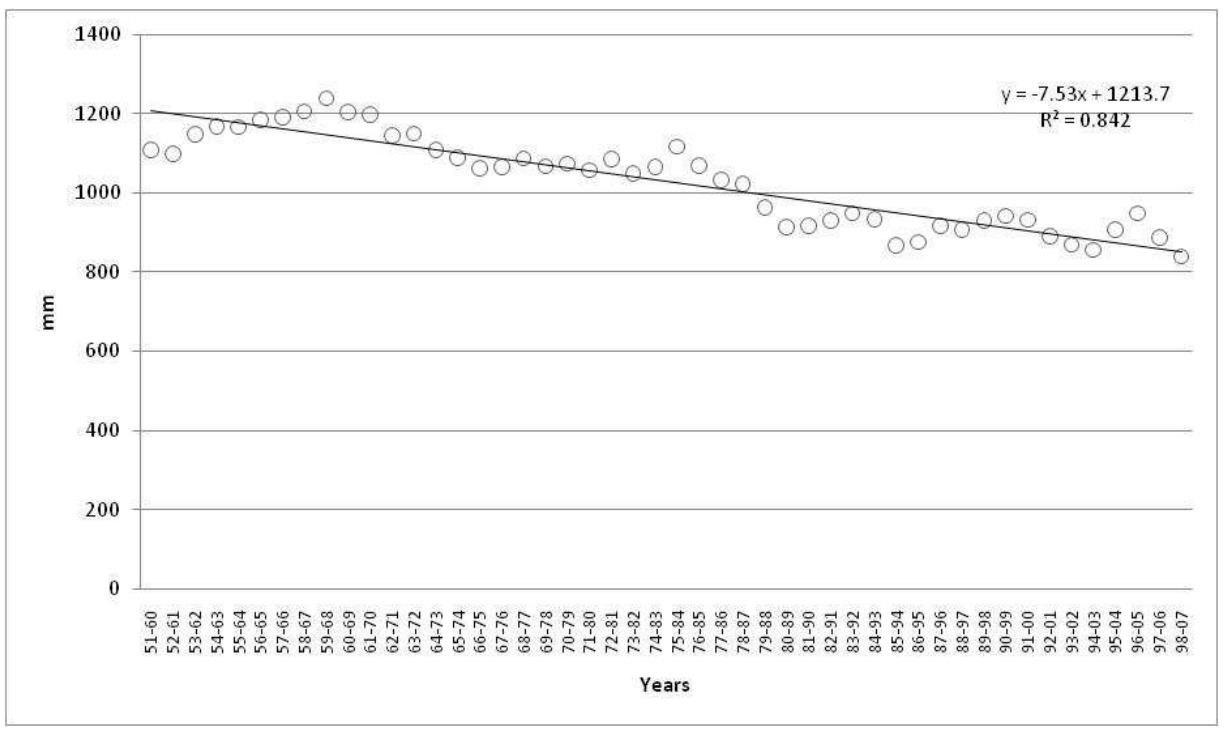

Figure 3. Moving average of annual rainfall measured at the Rota station with the related trend line and $R$-squared value

\section{Temperature regimes}

The Ordinary Kriging map of annual medium temperature is showed in Fig. 4. The coastal area of Civitavecchia showed to be the hottest area, while the Tolfa hilly area the coldest one.

During the period 1951-1980 (Table 2) the hottest months were August and July, with average medium temperatures between $21.6{ }^{\circ} \mathrm{C}$ (Allumiere) and $23.9{ }^{\circ} \mathrm{C}$ (Civitavecchia 2). Gauging stations that are located along the coast (stations of Civitavecchia, Fregene, Ladispoli, Maccarese, Palo Laziale 2, Pantano Tarquinia, Tarquinia 1 and Tarquinia 2) registered an average annual temperature of $15.9{ }^{\circ} \mathrm{C}$. In inland areas (Allumiere, Anguillara Sabazia, Bracciano 1, Cerveteri 2, Rota, Sasso Furbara and Vigna di Valle) the average annual temperature was lower $\left(14.8^{\circ} \mathrm{C}\right)$. The highest value of the monthly average of maximum temperature $\left(27.5^{\circ} \mathrm{C}\right)$ was registered at the gauging station of Maccarese. The coldest month was January with the lowest values for Allumiere $\left(6.5^{\circ} \mathrm{C}\right.$ medium temperature and $3.3{ }^{\circ} \mathrm{C}$ minimum temperature). The average minimum temperatures never fell below $0{ }^{\circ} \mathrm{C}$, except in one monthly registration at Vigna di Valle $\left(-1.4^{\circ} \mathrm{C}\right.$ in February 1956).

During the period 1978-2007 (Table 2) the hottest months were July and August, with average temperatures between $22.2{ }^{\circ} \mathrm{C}$ (Allumiere) and $25.1{ }^{\circ} \mathrm{C}$ (Civitavecchia 1). At sea level (same stations as above), the average annual temperature was $16.6{ }^{\circ} \mathrm{C}$, while in the inland area was lower $\left(15.2{ }^{\circ} \mathrm{C}\right)$. The highest values of maximum temperature were registered in August (mainly) with values ranging from $27.8{ }^{\circ} \mathrm{C}$ (Civitavecchia 1) to $26.3{ }^{\circ} \mathrm{C}$ in July at the station of Allumiere. The coldest months were January and February, with the lowest value for Allumiere $\left(6.1{ }^{\circ} \mathrm{C}\right.$ medium temperature and $3.4{ }^{\circ} \mathrm{C}$ minimum temperature). The average minimum temperature never fell below $0{ }^{\circ} \mathrm{C}$, except in one monthly registration of Allumiere $\left(-0.5^{\circ} \mathrm{C}\right.$, January of 1981).

In all stations, the comparison of the two temperature datasets indicated that the annual average temperature increased from $0.1{ }^{\circ} \mathrm{C}$ to $1.0{ }^{\circ} \mathrm{C}$. The increase in 
temperature was higher for minimum temperature than for maximum temperature, generally for all the considered stations. In all stations, the maximum temperature increased during the Summer, with a variable trend for the other seasons. The moving averages of mean annual temperature (calculated for the thermo-gauging stations) generally showed an increasing trend. Fig. 5 shows the moving average of the minimum annual temperature of the station of Vigna di Valle.
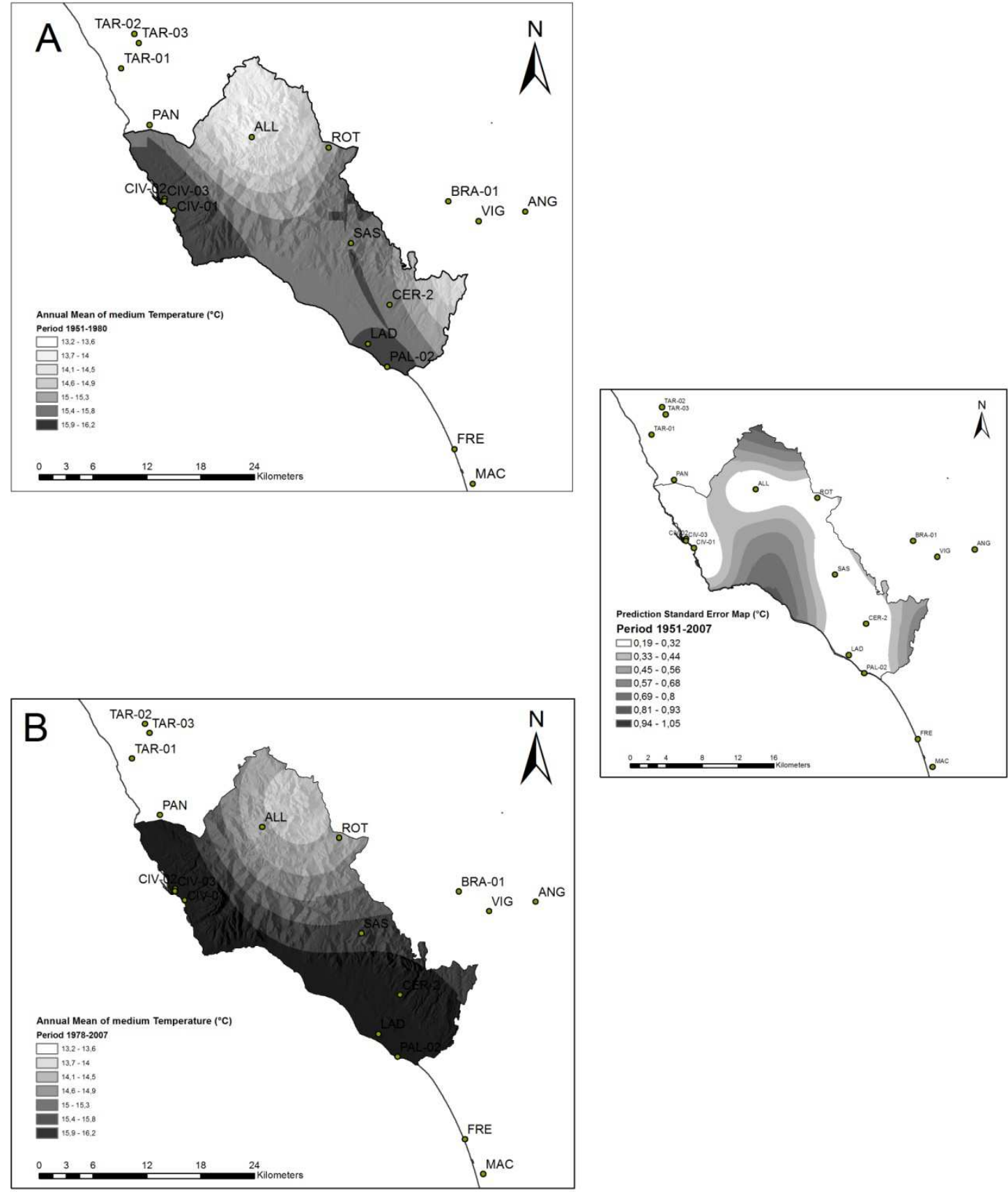

Figure 4. Ordinary Kriging spatialization of annual mean medium temperature (in $\left.{ }^{\circ} \mathrm{C}\right)$ considering the periods 1951-1980 (a) and 1978-2007 (b) and standard error map related to the whole period 
Table 2. Average monthly and annual values of medium temperature (in ${ }^{\circ} \mathrm{C}$ ) for the two periods (1951-1980 and 1978-2007). The variation in temperature was calculated subtracting the more recent period to the first one. The coldest months are in bold, the hottest months in italic

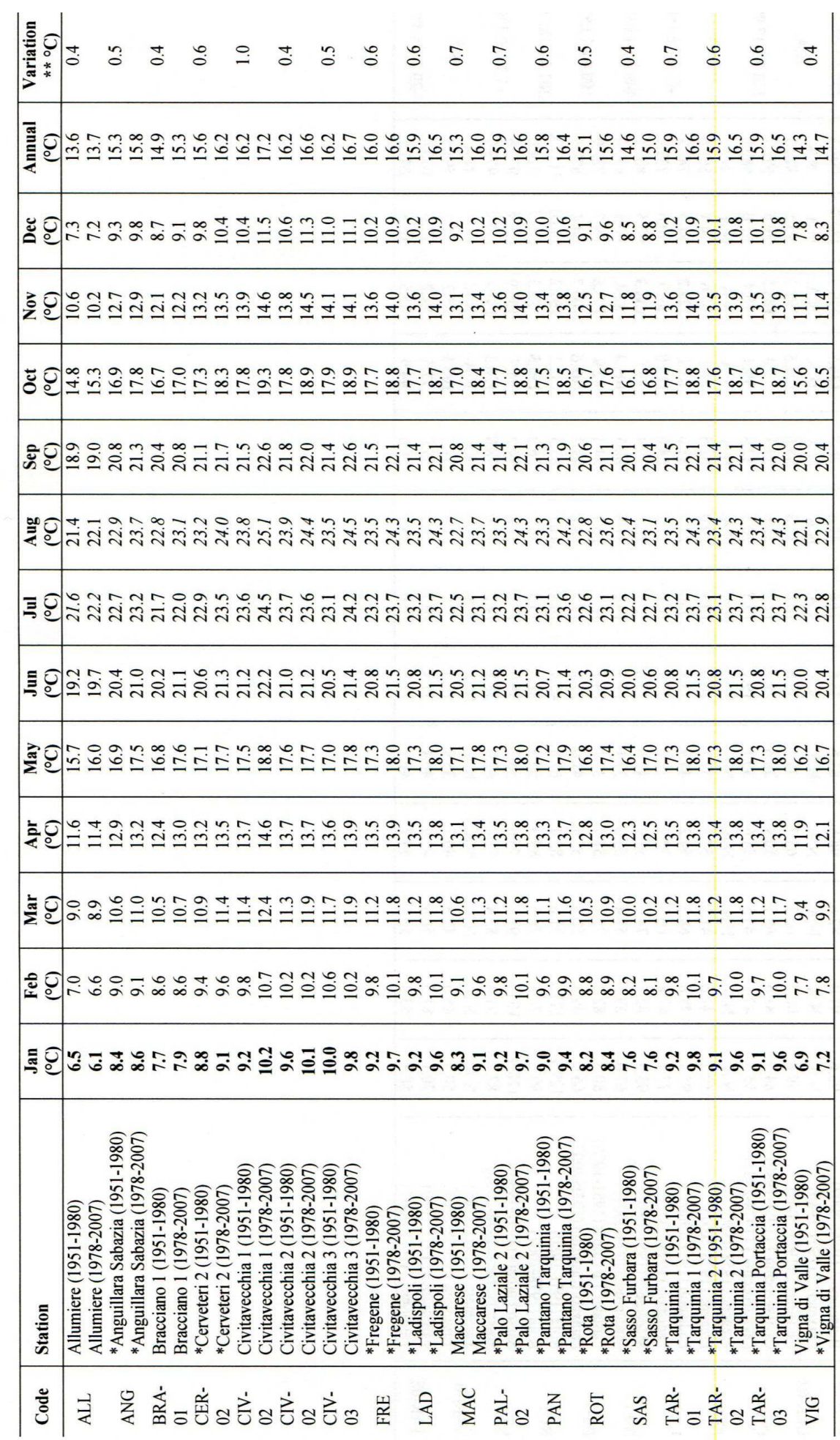

* Values interpolated using the linear regression method. 


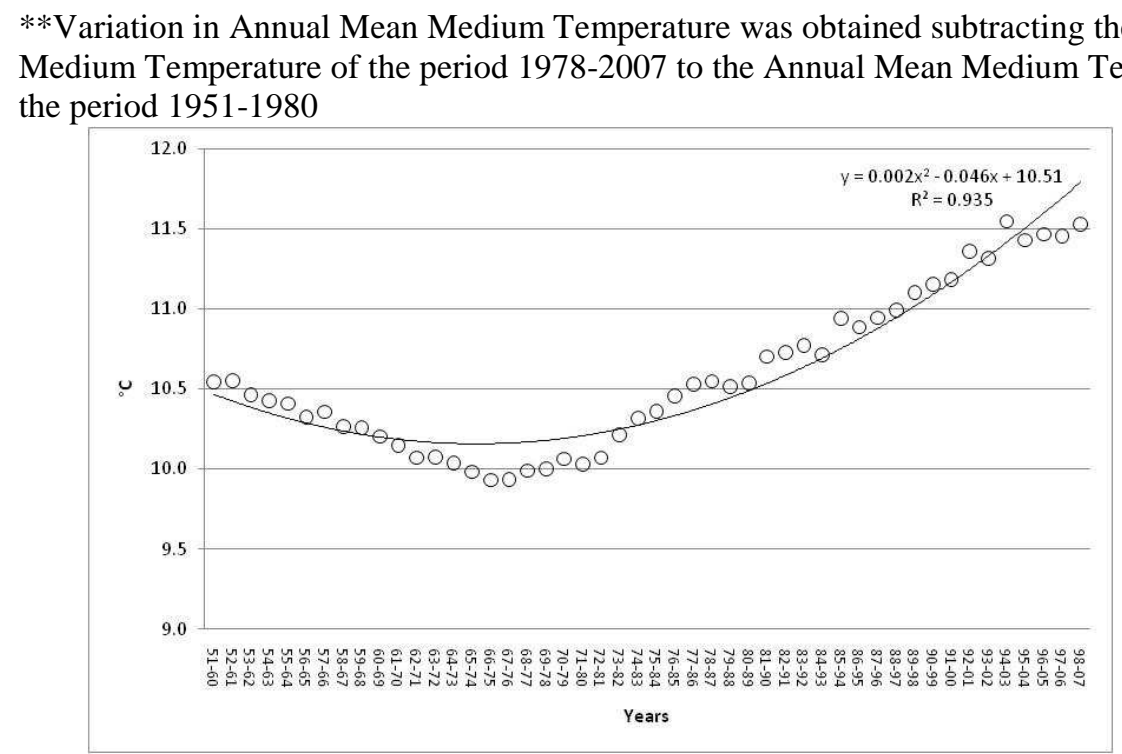

Figure 5. Moving average of the annual minimum temperature at the station of Vigna di Valle with the related trend line and $R$-squared value

\section{Bioclimatic Indexes}

During the period 1951-1980 (Table 3), the calculation of Mitrakos indexes showed that the station with the higher drought stress (both annual and Summer) was Civitavecchia 1. The station with the highest cold stress (both annual and Winter) was Allumiere. According to the bioclimatic classification of Emberger (Q), all stations with available data were classified as humid. According to the elaboration of Rivas Martinez indexes, all the gauging stations belonged to the Mediterranean area, excluding Bracciano, Anguillara Sabazia and Rota, which classified within the Temperate area. The values of the BGI indicated a humid climate for all the stations.

During the period 1978-2007 (Table 3), the calculation of Mitrakos indexes showed that the station with the highest drought stress (both annual and Summer) was Fregene. The station with the highest cold stress (both annual and Winter) was Allumiere. According to the bioclimatic classification of Emberger (Q), Allumiere, Anguillara Sabazia, Bracciano 1, Cerveteri 2, Ladispoli, Rota, Sasso Furbara and Tarquinia 2 were humid, while Civitavecchia 1, Fregene, Maccarese, Pantano Tarquinia and Tarquinia 1 were sub-humid. According to the elaboration of Rivas Martinez indexes all the gauging stations belonged to the Mediterranean area.

The comparison of Mitrakos indexes shows that, for all the stations, the annual and Winter cold stresses have markedly decreased in a percentage ranging from $1.3 \%$ to $31.7 \%$. Summer drought stress has increased for the majority of stations (not for Ladispoli); the annual drought stress has increased too (but not for Ladispoli and Tarquinia 2). The Emberger biclimatic classification of Civitavecchia 1, Fregene, Maccarese, Pantano Tarquinia and Tarquinia 1 shifted from humid to sub humid. According to the Rivas Martinez classification all the stations that were classified as Temperate shifted into the Mediterranean belt. According to the Rivas Martinez classification three stations (Allumiere, Bracciano 1 and Rota) change their ombrotype (Rivas Martinez 1993) from humid to sub-humid; other three other stations (Civitavecchia 1 and Maccarese and Pantano Tarquinia) changed from sub-humid to dry. The variations of the BGI values over the two periods are showed in Fig. 6. 
Table 3. Bioclimatic Indexes values for the two periods (1951-1980 and 1978-2007). YCS= Year Cold Stress; WCS = Winter Cold Stress; YDS= Year Drought Stress; SDS= Summer Drought Stress; $Q=$ Emberger rainfall index; $A I=$ De Martonne Aridity Index; IT= Thermicity Index; Ic = Continentality Index; IO= Ombrothermic Index; IOS $2=$ Ombrothermic Index of the warmest two months of Summer; IOS3= Ombrothermic Index of Summer; IOS4= Ombrothermic Index of Summer plus the previous month); BGI= BagnoulsGaussen Aridity Index

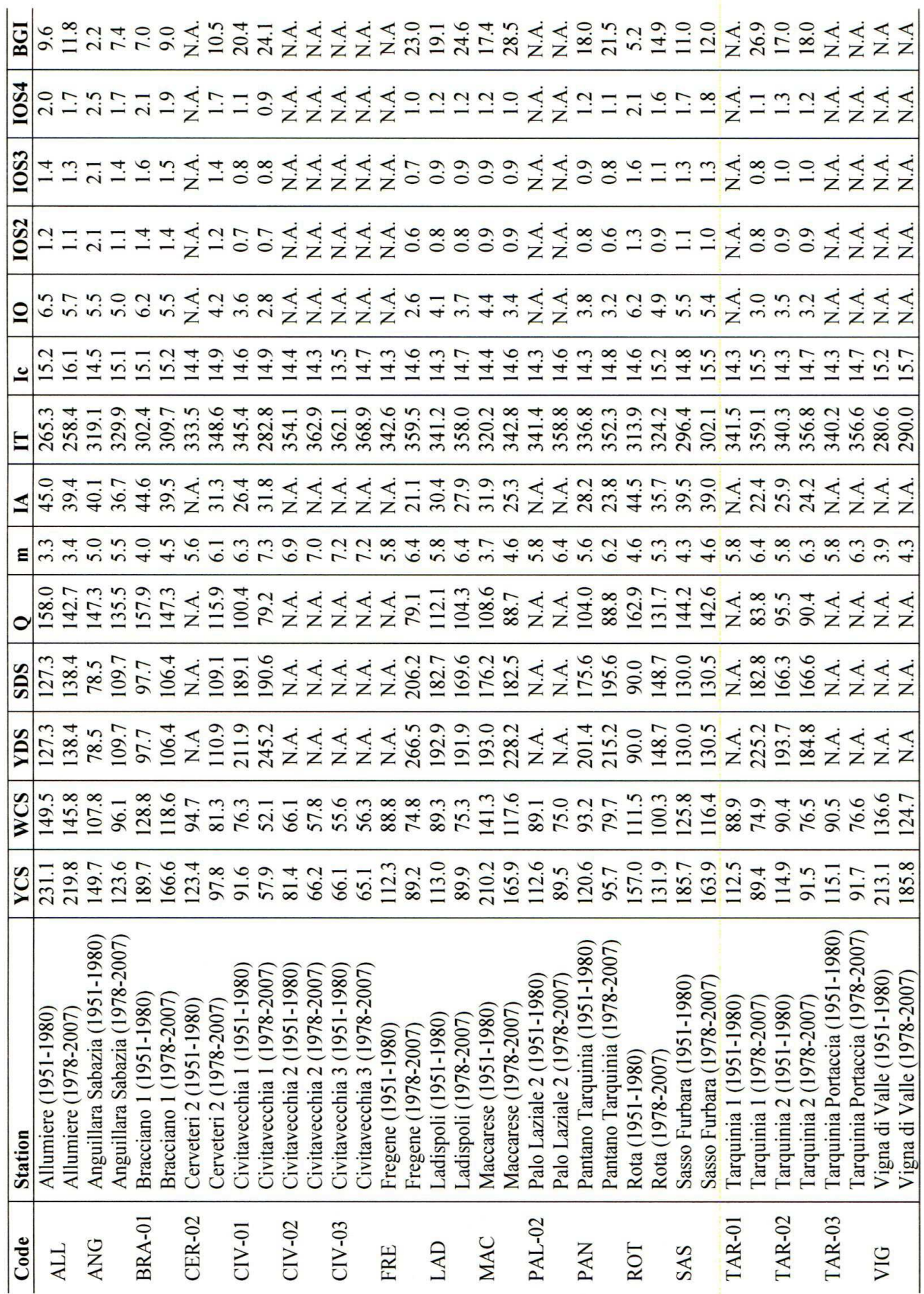

N.A.=Not Available 

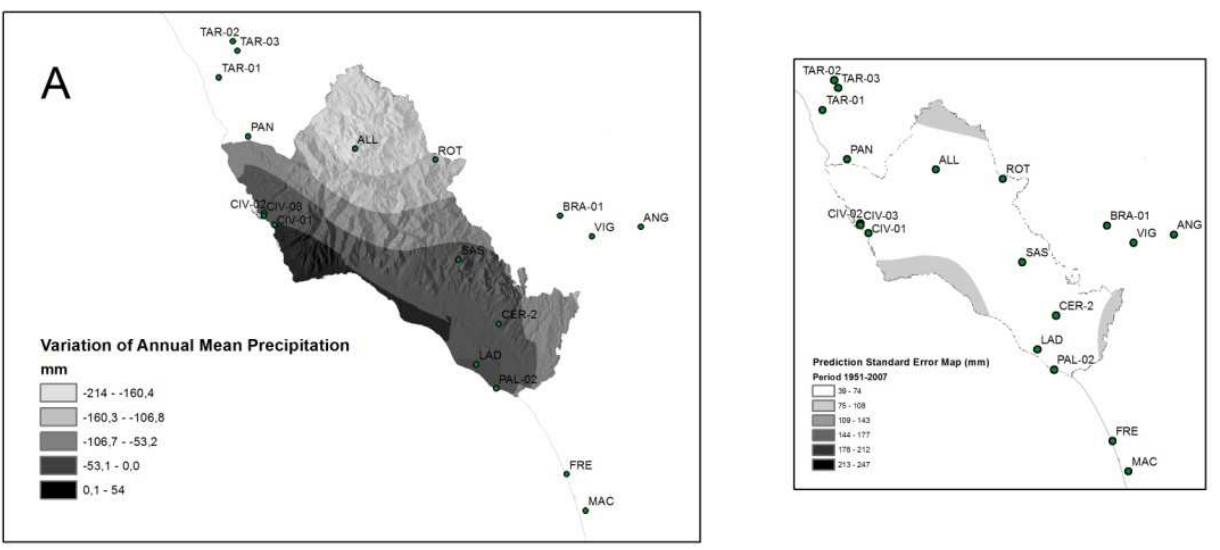

$\bigwedge^{N}$
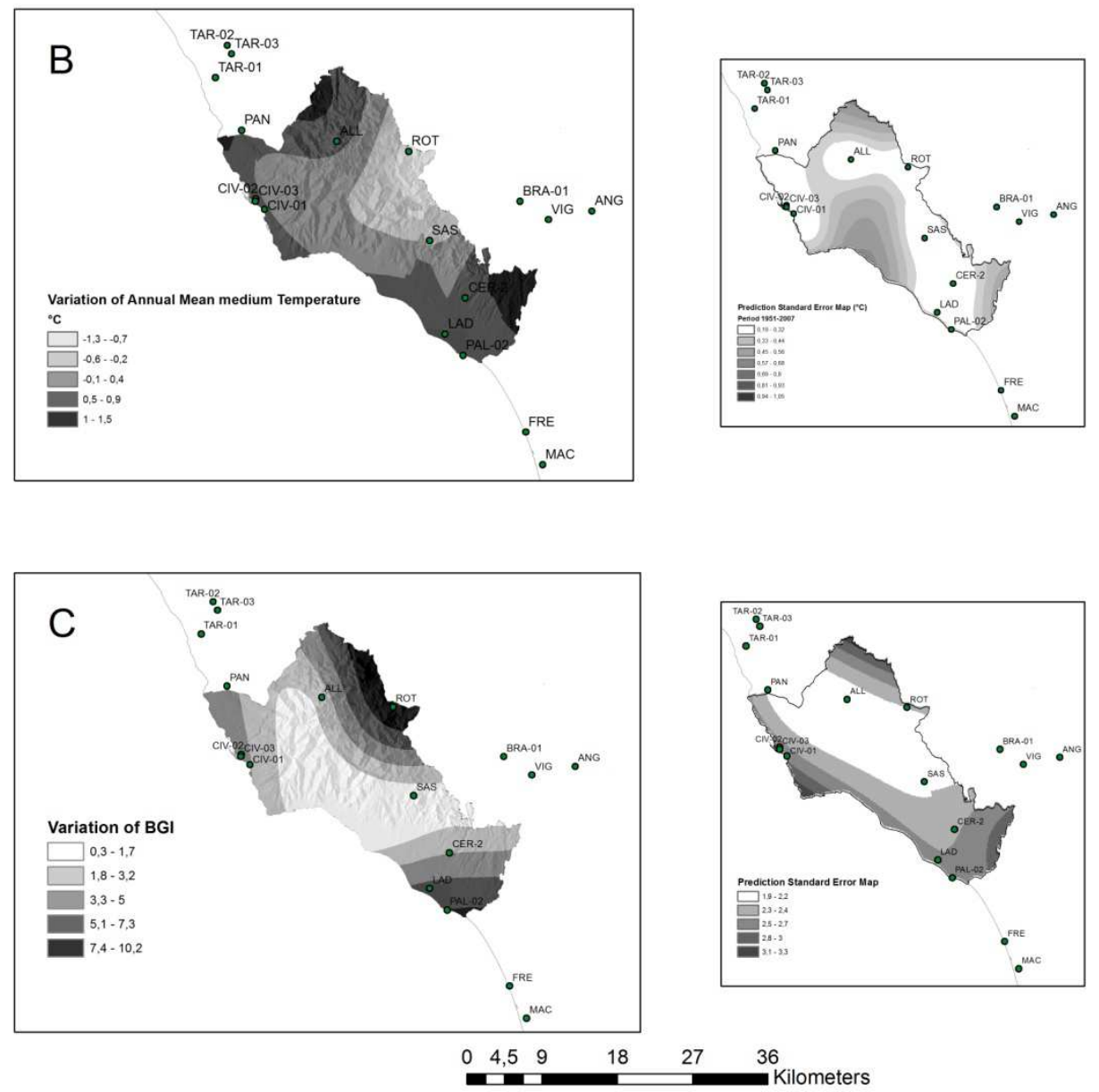

Figure 6. Ordinary Kriging spatialization of the variation of the annual mean precipitation (a), annual mean of medium temperature (b) and of the BGI value (c). Related standard error maps are on the right

\section{Climate change and vegetation}

According to our analyses, the broadleaf forests are the most affected by decrease in annual rainfall amount (Table 4) in the study area. Woodlands belonging to the 
vegetation association Carpino-betuli-Coryletum avellanae, which are located in narrow valleys on tuff substrata (Fanelli et al., 2007), were subjected to an average decrease of rainfall of $196.4 \mathrm{~mm}$ over thirty years (the whole area, on average, had a annual rainfall of $896.3 \mathrm{~mm}$ for the period 1951-1980 and of $767.2 \mathrm{~mm}$ for the second period). Temperate woodlands dominated by Quercus robur L. (Hieracio racemosi-Quercetum petraeae Pedrotti, Ballelli, Biondi 1982) experienced a decrease in rainfall that ranges from a minimum of $46.0 \mathrm{~mm}$ to a maximum of $214.3 \mathrm{~mm}(-188.7 \mathrm{~mm}$ on average). Chestnut forests of the Carpinion alliance, located on acid vulcanite soils, experienced an average decrease of $187.0 \mathrm{~mm}$ while the forest communities dominated by Fagus sylvatica L. and Ilex aquifolium L. [Anemono apenninae-Fagetum sylvaticae (Gentile 1969) Brullo 1984] in Allumiere were subjected to a decrease of $180.0 \mathrm{~mm}$ of rainfall (Fig. 7).

An average decrease of $161.2 \mathrm{~mm}$ of rainfall was calculated for the thermophilous sub-acidophilus woodland dominated by Quercus cerris L. [Rubio-Quercetum cerridis (Pignatti E. e S., 1968) Bas Petroli et al. (1988)], which is the most widespread woodland. Quercus ilex L. forests [Viburno-Quercetum ilicis (Br.-Bl. 1936) RivasMartinez, 1975] were not really affected by a decrease in rainfall (only $27 \mathrm{~mm}$ ). The acidophilus community Rusco aculeati-Quercetum ilicis Biondi, Gigante, Pignateli, Venanzoni 2002 var. Erica arborea L. experienced an average decrease of $144.0 \mathrm{~mm}$ of rainfall. Some pastures also faced an important reduction of rainfall: e.g., meadows with Gaudinia fragilis (L.) P. Beauv. and Cynosurus cristatus L. (-169.7 mm) (GaudinioCynosurietum cristati Fanelli 1997), prairies dominated by Dasypyrum villosum (L.) Borbàs (Vulpio-Dasypiretum Fanelli 1998) (-92.0 mm).

The plant communities more heavily affected by temperature increases are the igrophilous broadleaf woodlands of the flood plains. Specifically, the alluvial forests dominated by Alnus glutinosa (L.) Gaertn. (Aro italici-Alnetum glutinosae Pedrotti and Gafta 1996) and the riparian poplar woodlands (Populetum albae Tchou Yen-Cheng 1949) faced a temperature increase of $0.8{ }^{\circ} \mathrm{C}$ (average of the annual medium temperature). The alophilous and sub-alophilous communities of dunes experienced an increase of $0.7^{\circ} \mathrm{C}$. A moderate increase of temperature was also calculated for Castanea sativa forests of the Carpinion alliance $\left(0.5^{\circ} \mathrm{C}\right)$.

Aridity index calculations display that shrub communities faced the highest aridity increase, including evolving stadia of the Mediterranean Quercus cerris woodland (8.54) and communities of the Rusco aculeati-Quercetum ilicis Biondi, Gigante, Pignateli, Venanzoni 2002 var. Erica arborea L. (7.02). Woodlands of Carpinus betulus L. and Corylus avellana L. (Carpino betuli-Coryletum avellanae 1982 Ballelli, Biondi $\&$ Pedrotti 1980) (5.81) also faced an increase of aridity. Among the forests, an increase of aridity was also calculated for the re-colonizing woodland dominated by Quercus pubescens (Roso sempervirentis-Quercetum pubescentis Biondi 1986) (5.05) (BGI shifting from 0.58 to 9.98 in different localities). 
Table 4. Zonal statistic analysis of the annual mean precipitation, annual mean of medium temperature and of the BGI value [with the related surface area (Area), Minimum (min), Maximum (max), Mean (Mean) and standard deviation (STD)] in relation to vegetation syntaxa (from Fanelli et al., 2007, mod)

\begin{tabular}{|c|c|c|c|c|c|c|c|c|c|c|c|c|c|c|c|c|c|}
\hline & $\stackrel{n}{n}$ & 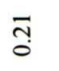 & : & å & ¿্口 & & $\stackrel{8}{-}$ & 8 & Бे & 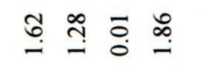 & $\overline{0}$ & $\stackrel{\overbrace{}}{0}$ & 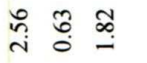 & $\stackrel{n}{n}$ & 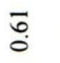 & & $E \stackrel{2}{=}$ \\
\hline 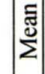 & के & $\tilde{\text { ते }}$ & $\frac{n}{i}$ & in & ڤి & ले & $\stackrel{m}{m}$ & in & కo & ڤั & $\stackrel{R}{0}$ & $\stackrel{\bar{\infty}}{\dot{n}}$ & 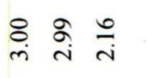 & $\stackrel{0}{\text { d }}$ & f & if & 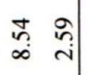 \\
\hline & $\stackrel{R}{+}$ & 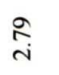 & $\stackrel{4}{A}$ & :ढ़ & n̊n & 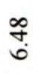 & 象 & in & So & 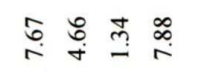 & הิ & $\stackrel{\infty}{\infty}$ & $\underset{\infty}{m} \stackrel{5}{\sigma}$ & $\stackrel{\infty}{2}$ & ț & ְ̊. & $\stackrel{\infty}{n} \stackrel{\infty}{\sim}$ \\
\hline & $\stackrel{0}{m}$ & $\stackrel{5}{g}$ & $\vec{i}$ & $\hat{n}$ & $\hat{n}$ & $\hat{3}$ & $\underset{0}{*}$ & in & : & 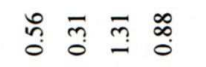 & : & $\stackrel{\text { fi }}{n}$ & $\stackrel{\widetilde{\sigma}}{\bar{\sigma}} \overline{\mathrm{s}}$ & ర్లి & $:$ & J & $\begin{array}{cc}0 & \bar{n} \\
\infty & 0\end{array}$ \\
\hline$\Xi$ & 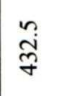 & $\frac{n}{\tilde{q}}$ & $\stackrel{n}{i}$ & ڤั่ & $\because$ & $\frac{n}{a}$ & స్ & $\stackrel{n}{n}$ & $\stackrel{n}{2}$ & 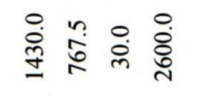 & $\stackrel{n}{n}$ & $\stackrel{\circ}{\circ}$ & 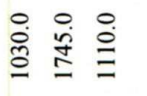 & 苚 & $\underset{\stackrel{i}{n}}{\stackrel{i}{N}}$ & ì & 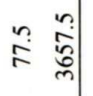 \\
\hline 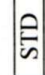 & $\begin{array}{l}\text { స్ } \\
\text { ల్ }\end{array}$ & $\stackrel{8}{\circ}$ & $\mp$ & $\stackrel{\pi}{-}$ & స్. & $\overline{\bar{\infty}}$ & $\begin{array}{l}\stackrel{\infty}{+} \\
\stackrel{i}{N}\end{array}$ & $\stackrel{8}{\circ}$ & ?ै & 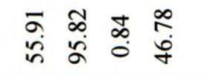 & $\stackrel{m}{0}$ & s. & 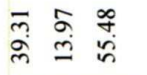 & $\begin{array}{l}\infty \\
0 \\
b \\
f\end{array}$ & 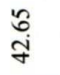 & ల్రి & $\begin{array}{ll}n & t \\
\vdots & 0\end{array}$ \\
\hline एँ & $\begin{array}{l}\infty \\
\tilde{i} \\
\hat{i}\end{array}$ & $\begin{array}{l}\text { Oे } \\
\stackrel{0}{1}\end{array}$ & $\begin{array}{l}\bar{y} \\
\bar{y}\end{array}$ & $\stackrel{\infty}{m}$ & $\stackrel{\infty}{-}$ & $\frac{7}{7}$ & ָे & 豙 & $\overbrace{\substack{0 \\
0}}^{\infty}$ & 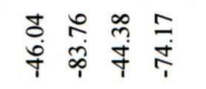 & $\stackrel{\text { d }}{\stackrel{4}{2}}$ & \begin{tabular}{l} 
7 \\
\multirow{0}{0}{}
\end{tabular} & 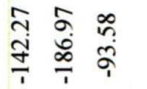 & 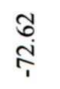 & $\begin{array}{l}\infty \\
0 \\
0 \\
0 \\
0\end{array}$ & $\frac{m}{m}$ & 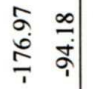 \\
\hline & $\begin{array}{l}\stackrel{\infty}{\varrho} \\
\varrho\end{array}$ & 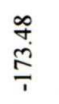 & $\frac{\dot{f}}{\text { J }}$ & $\underset{\text { d }}{\text { in }}$ & สิ & గ్ & 年 & 党 & م & 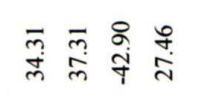 & ì & $\begin{array}{l}\frac{ \pm}{\mathrm{m}} \\
\frac{1}{1}\end{array}$ & 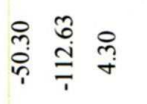 & \begin{tabular}{l}
$\infty$ \\
\multirow{j}{*}{} \\
$\dot{j}$
\end{tabular} & $\begin{array}{l}n \\
\text { ñ } \\
\frac{1}{1}\end{array}$ & in & 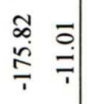 \\
\hline 5 & 芦 & $\begin{array}{l}\underset{\bar{\sigma}}{+} \\
\frac{\dot{0}}{i}\end{array}$ & $\begin{array}{l}3 \\
\dot{8} \\
\dot{y}\end{array}$ & సે & $\stackrel{8}{9}$ & $\begin{array}{c}\tilde{丶} \\
\hat{i}\end{array}$ & 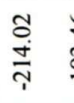 & $\frac{1}{2}$ & ס. & 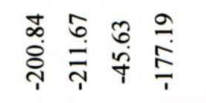 & $\stackrel{\infty}{\infty}$ & $\begin{array}{l}\frac{g}{\text { Gे }} \\
\frac{\text { oे }}{1}\end{array}$ & 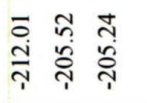 & $\begin{array}{l}\hat{n} \\
\stackrel{i}{i}\end{array}$ & 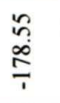 & $\stackrel{n}{i}$ & 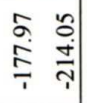 \\
\hline$<$ & $\ddot{q}$ & $\stackrel{0}{j}$ & $\stackrel{i}{i}$ & 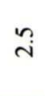 & $\stackrel{\infty}{\infty}$ & 苘 & हैं & ? & $\because$ & 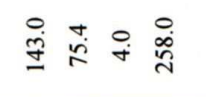 & $\because$ & $\because$ & 苦 $\stackrel{m}{g} \stackrel{9}{\Xi}$ & స్ & $\stackrel{\bar{\omega}}{\stackrel{N}{N}}$ & $\because$ & \\
\hline & $\frac{\infty}{0}$ & : & $\overline{0}$ & $\overline{0}$ & $\overline{0}$ & $\frac{n}{0}$ & st: & : & $\stackrel{8}{0}$ & 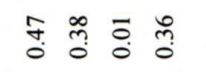 & $\stackrel{8}{0}$ & $\ddot{\circ}$ & 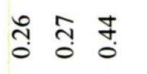 & f & $\frac{n}{0}$ & : & 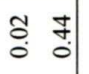 \\
\hline$\sum$ & $\frac{8}{4}$ & fo & 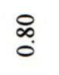 & 吕 & $\tilde{c}_{0}^{\infty}$ & int & $\stackrel{2}{0}$ & 告 & ڤે & $\bar{n}$ जी & สุ & กิ & t⿱艹 & $\overline{\dot{i}}$ & శิ & สิ & \\
\hline & $\bar{\Xi}$ & $\bar{n}$ & $\stackrel{\bar{\infty}}{\circ}$ & f. & हे & $\hat{o}$ & $\stackrel{\infty}{\infty}$ & $\frac{0}{\pi}$ & $\hat{\imath}$ & f. & กิ & $\stackrel{0}{a}$ & 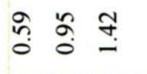 & $\bar{m}$ & $\stackrel{0}{\mathbb{0}}$ & กู่ & \\
\hline & $\stackrel{\circ}{\circ}$ & ริ & $\stackrel{\infty}{\circ}$ & $\stackrel{\infty}{\tilde{c}}$ & $\stackrel{\infty}{3}$ & สิ & $\begin{array}{l}\hat{\imath} \\
\stackrel{i}{i}\end{array}$ & $\stackrel{t}{0}$ & $\stackrel{\infty}{\stackrel{0}{0}}$ & 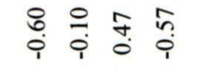 & กิ่ & สิ & 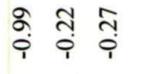 & ô & $\stackrel{8}{\circ}$ & กิ่ & 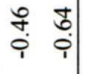 \\
\hline$\frac{\pi}{\pi}$ & $\stackrel{m}{q}$ & $\stackrel{\infty}{\xi}$ & $\stackrel{\infty}{\sim}$ & $\stackrel{i}{i}$ & $\stackrel{\infty}{\infty}$ & 离 & हे & ? & $\stackrel{\infty}{\infty}$ & 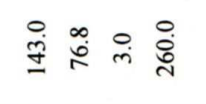 & $\stackrel{\infty}{\circ}$ & $\stackrel{\circ}{-}$ & 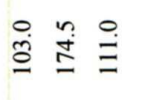 & 䒘 & $\stackrel{n}{\frac{n}{N}}$ & $\because$ & \\
\hline & 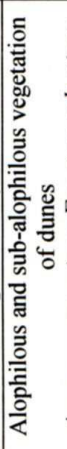 & 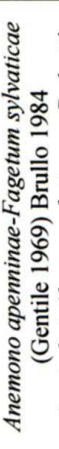 & 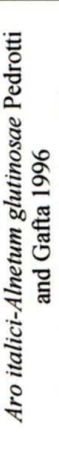 & 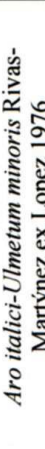 & & & $\begin{array}{l}0 \\
0 \\
8\end{array}$ & & 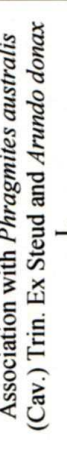 & 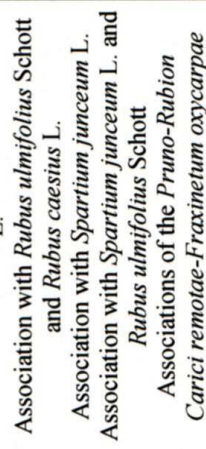 & 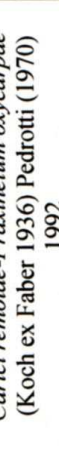 & 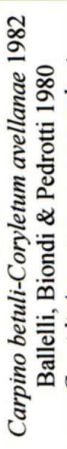 & 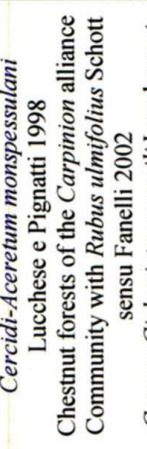 & 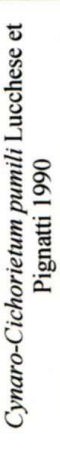 & 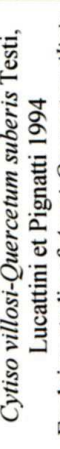 & 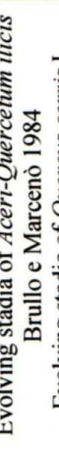 & 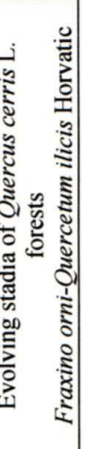 \\
\hline
\end{tabular}




\begin{tabular}{|c|c|c|c|c|c|c|c|c|c|c|c|c|c|c|c|}
\hline ले & $\stackrel{\infty}{-}$ & 䇍 & $\stackrel{\tilde{O}}{i}$ & 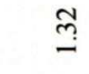 & $\hat{a}$ & $\stackrel{8}{0}$ & $\stackrel{?}{i}$ & ○응 & $\stackrel{\substack{0 \\
i}}{i}$ & $\stackrel{n}{i}$ & $\hat{i}$ & 赵 & $\stackrel{5}{0}$ & $\begin{array}{l}\infty \\
\infty \\
0\end{array}$ & \\
\hline in & $\bar{m}$ & $\stackrel{f}{q}$ & $\stackrel{\text { s. }}{i}$ & $\stackrel{\bar{\infty}}{-}$ & à & $\stackrel{\infty}{\stackrel{-}{-}}$ & $\stackrel{d}{i}$ & 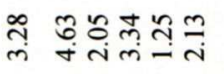 & $\stackrel{\leftrightarrow}{\circ}$ & & $\stackrel{\Xi}{\sim}$ & $\frac{m}{m}$ & تே. & $\stackrel{g}{g}$ & \\
\hline$\stackrel{\substack{\infty \\
m}}{n}$ & $\underset{\infty}{R}$ & $\frac{2}{4}$ & 卢. & $\tilde{\alpha}$ & ก̂ & $\stackrel{\infty}{\circ}$ & $\stackrel{m}{\circ}$ & 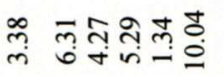 & $\stackrel{\infty}{\circ}$ & & $\underset{\infty}{\infty}$ & $\stackrel{\circ}{\circ}$ & 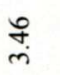 & : & $\begin{array}{c}\infty \\
\infty \\
\infty \\
0\end{array}$ \\
\hline$\stackrel{\infty}{\infty}$ & $\stackrel{\infty}{\circ}$ & $\bar{a}$ & gे & ले & $\overrightarrow{+}$ & $\stackrel{0}{-}$ & mे & $\frac{\infty}{m} \stackrel{0}{i}$ & $\stackrel{\infty}{n}$ & $\stackrel{5}{0}$ & తి & fi. & లి & @ె & 0 \\
\hline$\frac{n}{5}$ & 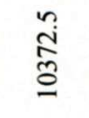 & 嵩 & $\underset{n}{n}$ & 离 & 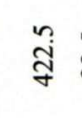 & $\stackrel{n}{\pi}$ & 字 & 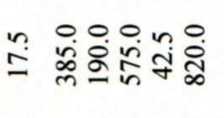 & $\stackrel{n}{\stackrel{n}{n}}$ & 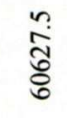 & i. & 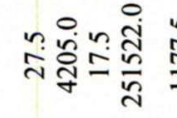 & & 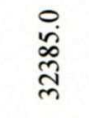 & \\
\hline$\stackrel{t}{0}$ & $\stackrel{\bar{a}}{\bar{\lambda}}$ & $\underset{\infty}{\infty}$ & 迎 & กี่ & gे & 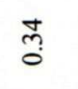 & ڤై & 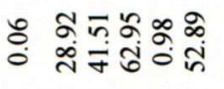 & $\stackrel{\infty}{\stackrel{\infty}{0}}$ & & $\begin{array}{l}\infty \\
\infty \\
\infty \\
n\end{array}$ & $\stackrel{B}{\infty}$ & 台 & $\frac{8}{5}$ & \\
\hline$\frac{\text { }}{8}$ & $\begin{array}{l}\frac{1}{\infty} \\
\substack{\infty \\
\infty}\end{array}$ & $\stackrel{8}{\circ}$ & $\underset{\substack{T \\
T}}{+}$ & $\begin{array}{l}\infty \\
0 \\
0 \\
\vdots \\
1\end{array}$ & 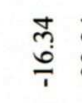 & $\underset{m}{\oplus}$ & $\begin{array}{l}\infty \\
\stackrel{0}{\oplus} \\
\stackrel{1}{1}\end{array}$ & 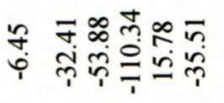 & $\begin{array}{l}\frac{j}{m} \\
\stackrel{g}{7}\end{array}$ & $\frac{\text { पे }}{\square}$ & 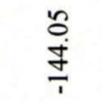 & 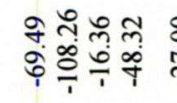 & 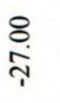 & $\stackrel{8}{m}$ & 9 \\
\hline $\begin{array}{l}\hat{\pi} \\
\substack{1 \\
0}\end{array}$ & $\begin{array}{l}\bar{y} \\
\dot{q} \\
\dot{0}\end{array}$ & $\begin{array}{l}\hat{b} \\
\stackrel{+}{+}\end{array}$ & $\begin{array}{l}n \\
n \\
y\end{array}$ & $\begin{array}{l}\infty \\
\stackrel{\infty}{\sim} \\
\stackrel{\sim}{1}\end{array}$ & $\stackrel{\Re}{\stackrel{\Re}{\leftrightarrows}}$ & 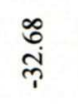 & ๙ิ้ & 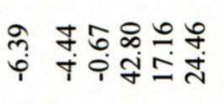 & $\begin{array}{l}\infty \\
\stackrel{\text { iे }}{ }\end{array}$ & $\begin{array}{l}\hat{R} \\
\stackrel{\rho}{i}\end{array}$ & $\begin{array}{l}\text { : } \\
\text { i }\end{array}$ & ơ & $\stackrel{0}{i}$ & 息 & \\
\hline 容 & $\underset{\stackrel{\infty}{+}}{\stackrel{\infty}{\uparrow}}$ & $\stackrel{?}{9}$ & 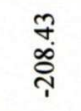 & $\begin{array}{l}8 \\
\dot{b} \\
\frac{1}{1}\end{array}$ & $\begin{array}{l}\infty \\
\stackrel{\Upsilon ิ}{\Lambda े ~}\end{array}$ & $\stackrel{\infty}{\infty}$ & 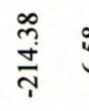 & 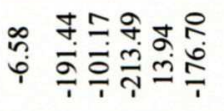 & $\frac{\hat{T}}{\stackrel{4}{+}}$ & 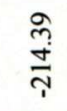 & 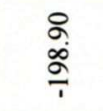 & 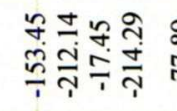 & 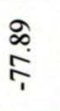 & 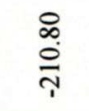 & \\
\hline$\stackrel{?}{?}$ & $\overline{\underline{0}}$ & 范 & $\underset{m}{\stackrel{H}{m}}$ & 胥 & $\stackrel{\text { g }}{3}$ & $\stackrel{n}{i}$ & 莳 & $\stackrel{\infty}{-\infty}$ & สิ่ & 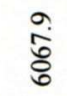 & $\stackrel{\infty}{m}$ & 苦 & $\stackrel{\mathscr{\infty}}{=}$ & तై & in \\
\hline$\stackrel{0}{0}$ & స్ర & ָิ & ले & fo & @̊ & ¿̈. & $\begin{array}{c}n \\
0 \\
0\end{array}$ & 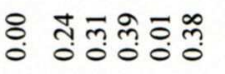 & $\stackrel{\circ}{0}$ & ڤి & $\hat{\imath}$ & F & $\frac{7}{0}$ & กี & 0 \\
\hline$\stackrel{\infty}{0}$ & ల్ల & $\bar{m}$ & $\stackrel{m}{0}$ & : & $\stackrel{\pi}{0}$ & $\frac{9}{0}$ & $\frac{9}{i}$ & 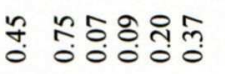 & : & $\stackrel{\infty}{0}$ & ఫे & సై & $\overline{7}$ & ô & o. \\
\hline $\bar{ָ}$ & $\stackrel{\infty}{\infty}$ & $\stackrel{\mathbb{I}}{\longrightarrow}$ & $\stackrel{\bar{\sigma}}{-}$ & $\stackrel{g}{=}$ & F & $\overline{\text { క్ }}$ & $\fallingdotseq$ & 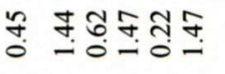 & $\stackrel{8}{\circ}$ & $\stackrel{\tilde{\sigma}}{-}$ & $\stackrel{n}{o}$ & f̧o & $\frac{0}{\pi}$ & $\stackrel{8}{\circ}$ & $\stackrel{0}{2}$ \\
\hline o̊ & î́ & 产 & to & 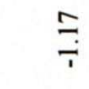 & $\stackrel{5}{0}$ & 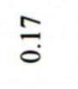 & $\underset{T}{T}$ & 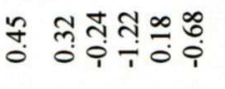 & $\stackrel{8}{\div}$ & $\stackrel{\text { Tे }}{i}$ & $\underset{T}{t}$ & 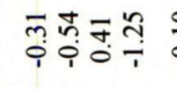 & $\frac{9}{i}$ & $\stackrel{8}{\circ}$ & \\
\hline$\stackrel{\infty}{0}$ & $\stackrel{m}{\frac{m}{\tilde{\theta}}}$ & : & $\stackrel{\infty}{\stackrel{\infty}{m}}$ & 告 & $\stackrel{3}{3}$ & $\stackrel{m}{i}$ & 芦 & 이 & $\stackrel{\infty}{\bar{\pi}}$ & 兽 & $\frac{n}{m}$ & 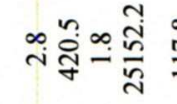 & $\stackrel{\infty}{\Xi}$ & $\begin{array}{l}n \\
\infty \\
\infty \\
\infty\end{array}$ & in \\
\hline 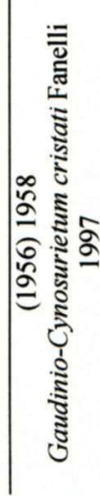 & 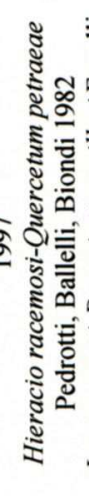 & 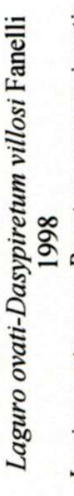 & 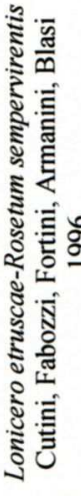 & 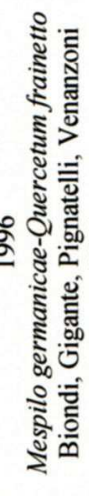 & 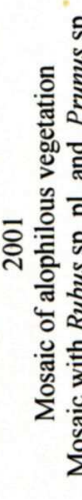 & 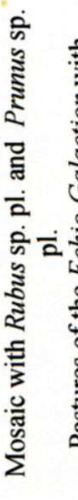 & 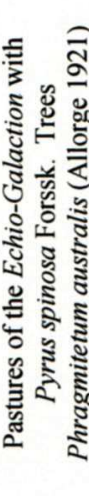 & 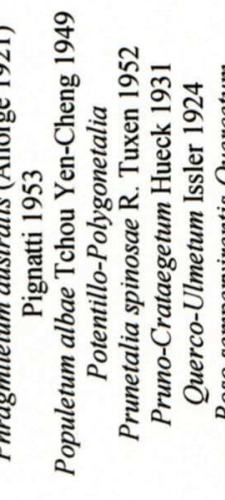 & 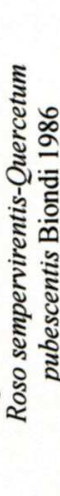 & 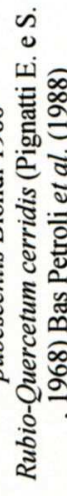 & 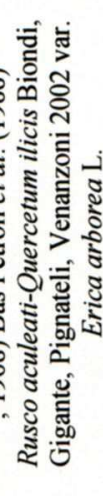 & 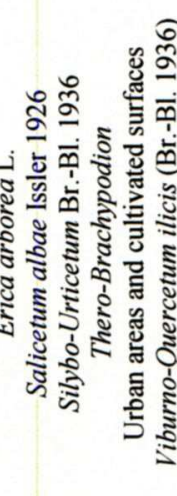 & 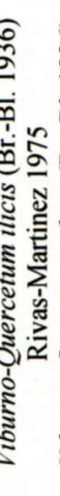 & 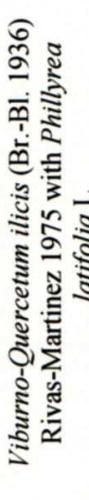 & 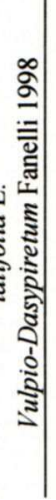 \\
\hline
\end{tabular}




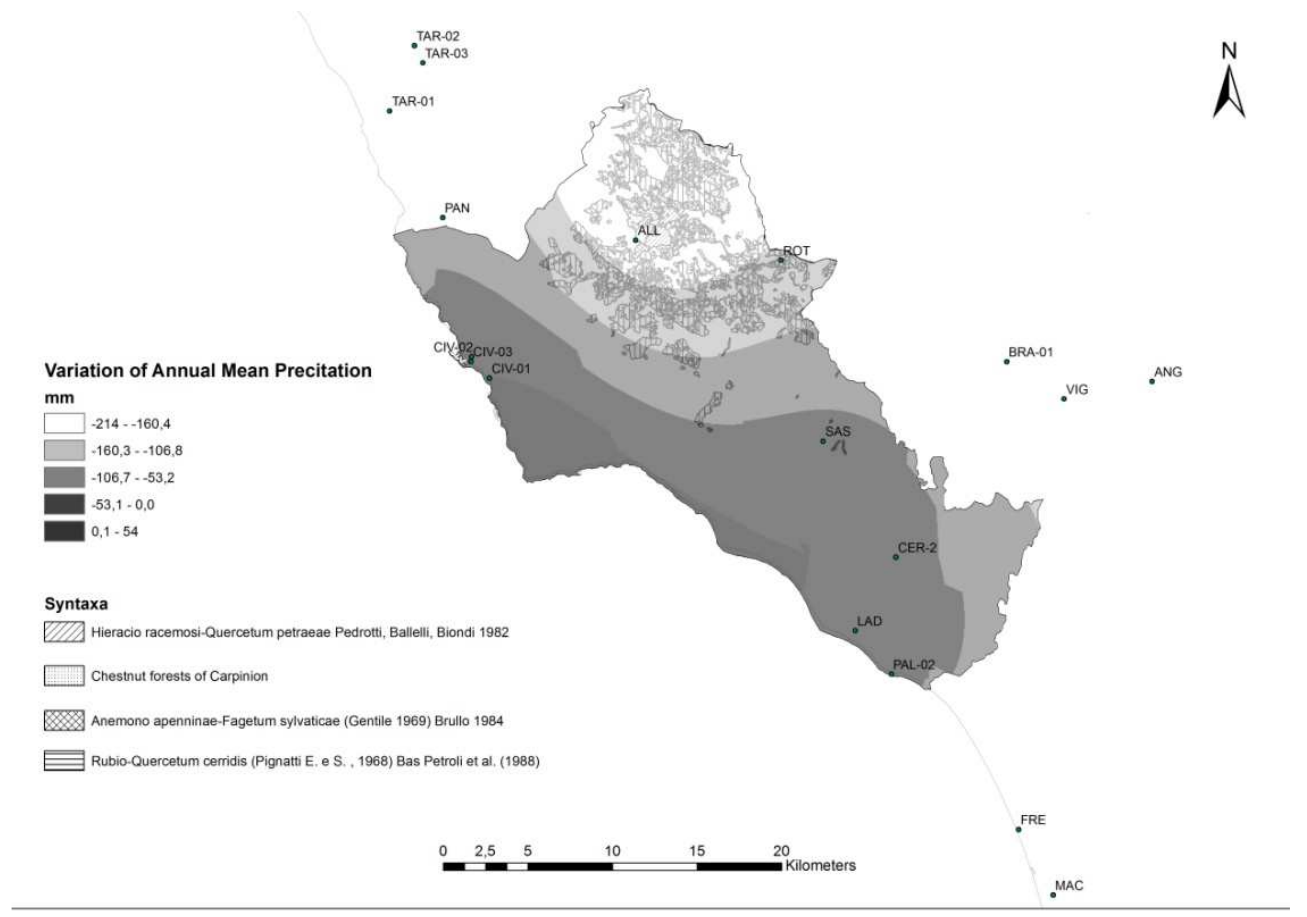

Figure 7. Forest communities (from Fanelli et al., 2007, mod.) in the area experiencing the highest decrease in annual rainfall

\section{Discussion}

Climate change is a cutting edge topic of research and it has been widely analyzed, predicted and forecasted at regional, national and supranational scale. However, how climate could change is still controversial (especially at local scale), as well as how it could impact plants and other living beings. In the Mediterranean basin, which has strong mesoscale features (Somot et al., 2008), local climatic studies can contribute to provide data in supporting or contrasting provisional models and theories at larger scale. Our research, developed in a Mediterranean-Temperate boundary area (Blasi et al., 1999) could provide useful data in this sense and create a positive background for further studies. Our approach tested different methods, bioclimatic and geostatical, to depict various aspects of the climate change in the Tolfa-Cerite area in relation to vegetation.

Our analysis seems to support the general negative trend in precipitation amount that has been observed in other Mediterranean areas (Giorgi and Lionello, 2008). Projected changes for the future (2071-2100) in rainfall consist in an average reduction of 8-36\% (minimum and maximum) in Central Italy (Giorgi and Lionello, 2008). According to our results, precipitations are currently decreasing at comparable rates. Moreover, an increase in temperature has been observed, even if this trend is less evident in the analyzed period. Projected changes in temperature (Giorgi and Lionello, 2008), for the same period, consist in an average increase of $2.7-4.2{ }^{\circ} \mathrm{C}$ (minimum and maximum). Analyses suggest that climate change in the study region is trending to greater aridity, and projections of climate change point to a further aridity increase. Current trends in climate conditions and future scenarios have implications for regional scale vegetation as it has been tested for some Mediterranean plant communities or species (MartinezVilalta et al., 2002; Thuiller et al., 2004; De Dato et al., 2008; Ogaya et al., 2011). 
It was observed a reduction in Autumn rainfall and this phenomenon may reduce the groundwater recharge. This reduction is partially balanced by a certain increase of rainfall during Summer, but this increase, which is expressed in percentage, correspond to a low increase in millimeters of rainfall. This phenomenon is in countertendency at projected increase of Summer drought. Geostatistical methods for the regionalization of rainfall were useful in defining its spatial distribution; the comparison of the two periods provided a visual and immediate output of changes in precipitation patterns. This analysis spotlights a clear decrease in rainfall amounts, especially in the hilly belt, while this decrease is less marked along the coast. This result may be useful in planning ad hoc management policies, especially as regards agriculture, irrigation, management of groundwater resources and natural vegetation conservation. Two out of the four forest communities that experienced the highest decrease in rainfall amount are listed in the Habitat Directive (92/43/CEE): the Castanea (9260) and Fagus forests (9210).

Changes in temperature are less evident, but these results might have been flattened by average values. However, it was possible to highlight a certain increasing trend in temperature, and this increase was higher for minimum than for maximum temperatures. In the study area it seems also that hilly areas were more affected by this increase in temperature values. This trend could be particularly worrying for the Tolfa area since there grow extra-zonal forests of Fagus sylvatica and other broad leaf woodlands. An increase of temperature seems to positively affect the growth of this species (Sabatè et al., 2002), but not if associated with a decrease in rainfall (Piovesan et al., 2008).

The area showed transitional bioclimatic features (Blasi et al., 1999) in the first analyzed period (1951-1980), but during the second period it is possible to highlight a reclassification of the whole area in the Mediterranean bioclimatic belt. This may indicate an ongoing process of vegetation shift, and probably also a change in plant distribution patterns but more analyses are required to better understand this ongoing processes.

In general, it seems that vegetation is experiencing a reduction of rainfall on the hilly belt and an increase of temperature on the coastal areas. However, it is not possible to quantify the possible effects of climate change on vegetation since long term studies are required to better understand this dynamic and complex interaction. A reduction of rainfall and an increase of temperature, together, lead to an increase in climate aridity which, however, is more marked on the hilly belt. Also, it is noteworthy that many forest associations are facing this problem with a greater extent than other plant communities. Among them, the less vulnerable, and the most affected by aridity, are the riparian forest and the broadleaf tree communities.

\section{Conclusions}

This study highlighted a variation in climatic conditions using different analyses and approaches. It also highlighted that these variations occurred in many areas covered by vulnerable plant communities. These variations may be particularly dangerous for extrazonal forests that usually grow at higher elevations and represent a very distinctive element of the landscape of the area. Moreover, a reduction in rainfall and a shift of precipitation patterns could reduce the recharge of groundwater, thus affecting both agriculture and water availability for the rapidly growing urban settlements in the area. Conservation policies and sustainable regional planning are needed to effectively 
protect these vulnerable plant communities. They may benefit from a permanent and integrated monitoring system of climate conditions and plant distribution.

Acknowledgements. Many thanks are due to Dr. Corrado Ingravallo and Anna Guidi (MS) of the Provincia di Roma for sharing with us the shape file of vegetation of the Province of Rome. Thanks are also due to Dr. Laura Cancellieri (University Roma Tre) for her support with the GIS analyses. Authors acknowledge also Dr Alessandro Cecili (University Roma Tre) for sharing the DEM raster database that was used in this research.

\section{REFERENCES}

[1] Angelelli, F., Faramondi, S. (1995): Lineamenti geologici della regione tolfetana. - Geo Archeol. 1: 11-50.

[2] Anzalone, B. (1961): Osservazioni fitosociologiche su alcune faggete depresse del Lazio. - Ann. Bot. 27(1): 120-134.

[3] Attorre, F., Alfò, M., De Sanctis, M., Francesconi, F., Bruno, F. (2007): Comparison of interpolation methods for mapping climatic and bioclimatic variables at regional scale. International Journal of Climatology 27(13): 1825-1843.

[4] Bachelet, D., Neilson, R.P., Lenihan, J.M., Drapek, R.J. (2001): Climate change effects on vegetation distribution and carbon budget in the United States. - Ecosystems 4: 164185.

[5] Bagnouls, F., Gaussen, H. (1953): Saison séche et indice xérothermique. - Docum. Pour les Cartes des Prod. Veget. Serie Generalité 1: 1-49.

[6] Benavides, R., Montes, F., Rubio, A., Osoro, K. (2007): Geostatistical modelling of air temperature in a mountainous region of Northern Spain. - Agr. Forest Meteorol. 146(34): $173-188$.

[7] Blasi, C. (1996): Il Fitoclima d'Italia. - Giornale Botanico Italiano 130(1): 166-176.

[8] Blasi, C. (2010): Il sistema ambientale: ecologia del paesaggio e rete ecologica. - In: AA.VV. (eds) Piano Territoriale Provinciale Generale (PTPG). http://ptpg.provincia.roma.it:8080/

[9] Blasi, C., Carranza, M.L., Filesi, L., Tilia, A., Acosta, A. (1999): Relation between climate and vegetation along a Mediterranean-Temperate boundary in central Italy. Global Ecology and Biogeography 8(1): 17-27.

[10] Bombi, P., D'Amen, M., Gerlach, J., Luiselli, L. (2009): Will climate change affect terrapin (Pelusios subniger paritalis and $\mathrm{P}$. castanoides intergularis) conservation in Seychelles? - Phelsuma 17A: 1-12.

[11] Ciais, P., Reichstein, M., Viovy, N., Granier, A., Ogee, J., Allard, V., Aubinet, M., Buchmann, N., Bernhofer, C., Carrara, A., Chevallier, F., De Noblet, N., Friend, A.D., Friedlingstein, P., Grunwald, T., Heinesch, B., Keronen, P., Knohl, A., Krinner, G., Loustau, D., Manca, G., Matteucci, G., Miglietta, F., Ourcival, J.M., Papale, D., Pilegaard, K., Rambal, S., Seufert, G., Soussana, J.F., Sanz, M.J., Schulze, E.D., Vesala, T., Valentini, R. (2005): Europe-wide reduction in primary productivity caused by the heat and drought in 2003. - Nature 437: 529-533.

[12] Contoli, L., Lombardi, G., Spada, F. (1980): Piano per un parco naturale nel territorio di Allumiere e Tolfa (Lazio). - Provincia di Roma, Istituto Poligrafico e Zecca dello Stato.

[13] Cresta, S., Fattori, C., Mancinella, D., Basilici, S. (2005): La geodiversità del Lazio. Geositi e Geoconservazione nel Sistema delle Aree Protette. - Edizioni ARP.

[14] Crookston, N.L., Rehfeldt, G.E., Dixon, G.E., Aaron, R., Weiskittel, A.R. (2010): Addressing climate change in the forest vegetation simulator to assess impacts on landscape forest dynamics. - Forest Ecol Manag 260: 1198-1211. 
[15] Cutini, M., Cancellieri, L., Cioffi, M.T., Licursi, C. (2010): Phytosociology and phytogeography of fragmented Alnus glutinosa forests in a Tyrrhenian district (Central Italy). - Ecologia Mediterranea 36(2): 55-73.

[16] De Dato, G., Pellizzaro, G., Cesaraccio, C., Sirca, C., De Angelis, P., Duce, P., Spano, D., Scarascia Mugnozza, G. (2008): Effects of warmer and drier climate conditions on plant composition and biomass production in a Mediterranean shrubland community. - iForest 1: 39-48.

[17] De Luís, M., García-Cano, F.M., Cortina, J., Raventós, J., González-Hidalgo, C.J., Sánchez, R.J. (2001): Climatic trends, disturbances and short-term vegetation dynamics in a Mediterranean shrubland. - Forest Ecol Manag 147(1): 25-37.

[18] De Martonne, E. (1926): Une nouvelle fonction climatologique: L'indice d'aridité. - La Meteorologie 2: 449-458.

[19] Devoto, G., Lombardi, G. (1977): Le formazioni sedimentarie ed eruttive del settore tolfetano-cerite- manziate (Lazio nordoccidentale). - Quad Acc Naz Lincei 227: 5-31.

[20] Eiji Maeda, E., Pellikka, P.K.E., Siljander, M., Clark, B.J.F. (2010): Potential impacts of agricultural expansion and climate change on soil erosion in the Eastern Arc Mountains of Kenya. - Geomorphology 123: 279-289.

[21] Di Pietro, R., Azzella, M.M., Facioni, L. (2010): The forest vegetation of the Tolfa-Ceriti Mountains (Northen Latium-Central Italy). - Hacquetia 9(1): 91-150.

[22] Emberger, L. (1955): Une classification biogéographique des climats. - Rev. Trav. Lab. Bot. Fac. Sci. 7: 3-43.

[23] Esteban-Parra, M.J., Rodrigo, F.S., Castro-Diez, Y. (1998): Spatial and temporal patterns of precipitation in Spain for the period 1880-1992. - International Journal of Climatology 18: $1557-1574$.

[24] Fanelli, G., Bertarelli, M., Bianco, P.M., Caroselli, V., Cazzagon, P., D’Angeli, D., De Corso, S., De Sanctis, M., Gioia, A., Guerra, A., Serafini Sauli, A., Testi, A., Pignatti, S. (2007): Carta della vegetazione della Provincia di Roma. - Provincia di Roma, Rome.

[25] Favis-Mortlock, D.T., Guerra, A.J.T. (1999): The implications of general circulation model estimates of rainfall for future erosion: a case study from Brazil. - Catena 37: 329354.

[26] Favis-Mortlock, D.T., Savabi, M.R. (1996): Shifts in rates and spatial distributions of soil erosion and deposition under climate change. - In: Anderson, M.G., Brooks, S.M. (eds) Advances in Hillslope Processes, Wiley, Chichester UK, pp. 529-560.

[27] Fiorillo, A.R., McCarthy, P.J. (2010): Ancient polar ecosystems and environments: Proxies for understanding climate change and global warming - an introduction. Palaeogeogr. Palaeoclimatol. Palaeoecol. 295: 345-347.

[28] Giacobbe, A. (1964): La misura del Bioclima mediterraneo. - Ann. Acc. Ital. Sci. Forest. 13: 37-69.

[29] Giavante, S., Di Giuseppe, E., Esposito, S. (2009): Flat steps models for the analysis of temperature and precipitation of Italian time series from 1961 to 2007. Statistical Methods for the analysis of large data-sets. - In: AA.VV. (eds) Book of short papers, Società Italiana di Statistica, Cleup Padova.

[30] Gibbons, J.W., Scott, D.E., Ryan, T., Buhlmann, K.A., Tuberville, T.D., Metts, B.S., Greene, J.L., Mills, T., Leiden, Y., Poppy, S., Winne, C.T. (2000): The Global Decline of Reptiles, Déjà Vu Amphibians. - BioScience 50: 653-666.

[31] Giorgi, F. (2006): Climate change hot-spots. - Geophysical Research Letters 33: L08707.

[32] Giorgi, F., Lionello, P. (2008): Climate change projections for the Mediterranean region. - Global Planet Change 63(2-3): 90-104.

[33] Goovaerts, P. (2000): Geostatistical approaches for incorporating elevation into the spatial interpolation of rainfall. - J. Hydrol. 228(1-2): 113-129.

[34] Hansen, J., Ruedy, R., Sato, M., Lo, K. (2006): GISS Surface Temperature Analysis. Global Temperature Trends: 2005 Summation. - NASA Goddard Institute for Space Studies and Columbia University Earth Institute, New York, USA. 
[35] Hansen, A.J., Neilson, R.P., Dale, V.H., Flather, C., Iverson, L.R., Currie, D.J., Shafer, S., Cook, R., Bartlein, P.J. (2001): Global change in forests: responses of species, communities, and biomes. - BioScience 51: 765-779.

[36] Hartkamp, A.D., De Beurs, K., Stein, A., White, J.W. (1999): Interpolation Techniques for climate variables. - NRG-GIS Series 99-01, CIMMYT, Mexico.

[37] Henderson-Sellers, A., Robinson, P.J. (1991): Contemporary Climatology. - Longman, London.

[38] Hoffmann, V.H., Sprengel, D.C., Ziegler, A., Kolb, M., Abegg, B. (2009): Determinants of corporate adaptation to climate change in winter tourism: An econometric analysis. Global Environ Change 19: 256-264.

[39] IPCC (2000): Summary for policymakers: emissions scenarios. - Special report of IPCC working group III.

[40] Iverson, L.R., Prasad, A.M. (1998): Predicting abundance of 80 tree species following climate change in the eastern United States. - Ecol. Monogr. 68: 465-485.

[41] Jackson, S.T., Overpeck, J.T. (2000): Responses of plant populations and communities to environmental changes of the late Quaternary. - Paleobiol. 26: 194-220.

[42] Jump, A.S., Penuelas, J. (2005): Running to stand still: adaptation and the response of plants to rapid climate change. - Ecol. Lett. 8: 1010-1020.

[43] Kutiel, H., Maheras, P. (1998): Variations in the temperature regime across the Mediterranean during the last century and their relationship with circulation indices. Theor. Appl. Climatol. 61: 39-53.

[44] Kutiel, H., Maheras, P., Guika, S. (1996): Circulation and extreme rainfall conditions in the Eastern Mediterranean during the last century. - International Journal of Climatology 16: 73-92.

[45] Jiao, J., Zou, H., Jia, Y., Wang, N. (2009): Research progress on the effects of soil erosion on vegetation. - Acta Oecol. Sin. 29(2): 85-91.

[46] Lavorel, S., Canadell, J., Rambal, S., Terrada, J. (1998): Mediterranean terrestrial ecosystems: research priorities on global change effects. - Global Ecol Biogeogr Lett 7: 157-166.

[47] Lionello, P., Malanotte-Rizzoli, P., Boscolo, R., Alpert, P., Artale, V., Li, L., Luterbacher, J., May, W., Trigo, R., Tsimplis, M., Ulbrich, U., Xoplaki, E. (2006): The Mediterranean climate: an overview of the main characteristics and issues. - In: Lionello, P., Malanotte-Rizzoli, P., Boscolo, R. (eds.), Mediterranean Climate Variability. Elsevier, Amsterdam, pp. 1-26.

[48] Lombardi, G. (2000): Inquadramento geomorfologico e geologico del comprensorio tolfetano. - In: Lombardi, G., Recrosio, A. (eds) Modello di Piano per la Tutela Ambientale e lo Sviluppo Socio-Economico di Aree di Interesse Naturalistico. Progetto per il Territorio di Allumiere e Tolfa, CNR and Università degli studi di Roma La Sapienza, Rome, pp 117-127.

[49] Maheras, P. (1988): Changes in precipitation conditions in the western Mediterranean over the last century. - Journal of Climatology 8: 179-189.

[50] Mandolesi, A. (1999): All'origine dell'Ager Tarquiniensis: il cantone meridionale tarquiniese nella prima età del Ferro. - In: AA.VV. (eds) Leopoli-Cencelle. Una città di fondazione papale, Le preesistenze, I. Roma, Palombi Editori, pp. 47-73.

[51] Martinez-Vilalta, J., Pinol, J., Beven, K. (2002): A hydraulic model to predict droughtinduced mortality in woody plants: an application to climate change in the Mediterranean. - Ecological Modelling 155: 127-147.

[52] Melillo, J.M., Borchers, J., Chaney, J., Fisher, H., Fox, S., Haxeltine, A., Janetos, A. (1995): Vegetation/Ecosystem Modeling and Analysis Project (VEMAP): comparing biogeography and biogeochemistry models in a continental-scale study of terrestrial ecosystem responses to climate change and $\mathrm{CO} 2$ doubling. - Global Biogeochem Cycles 9: 407-437. 
[53] Mendelsohn, R., Dinar, A. (2003): Climate, water, and agriculture. - Land Econ 79(3): 328-341.

[54] Mitrakos, K. (1980): A theory for Mediterranean plant life. - Acta Oecol. 1(3): 245-252.

[55] Nearing, M.A. (2001): Potential changes in rainfall erosivity in the U.S. with climate change during the 21st century. - J. Soil Water Conserv. 56(3): 229-232.

[56] Nearing, M.A., Jetten, V., Baffaut, C., Cerdan, O., Couturier, A., Hernandez, M., Le Bissonnais, Y., Nichols, M.H., Nunes, J.P., Renschler, C.S., Souchere, V., Van Oost, K. (2005): Modeling response of soil erosion and runoff to changes in precipitation and cover. - Catena 61: 131-154.

[57] Neilson, R.P., Pitelka, L.F., Solomon, A.M., Nathan, R., Midgley, G.F., Fragoso, J.M., Lischke, H., Thompson, K. (2005): Forecasting regional to global plant migration in response to climate change. - BioScience 55: 749-759.

[58] Ogaya, R., Penuelas, J., Asensio, D., Llusià, J. (2011): Chlorophyll fluorescence responses to temperature and water availability in two co-dominant Mediterranean shrub and tree species in a long-term field experiment simulating climate change. Environmental and Experimental Botany 73: 89-93.

[59] Osborne, C.P., Mitchell, P.L., Sheehy, J.E., Woodward, F.I. (2000): Modelling the recent historical impacts of atmospheric $\mathrm{CO} 2$ and climate change on Mediterranean vegetation. - Global Change Biol 6: 445-458.

[60] Palutikof, J.P., Conte, M., Casimiro Medes, J., Goodess, C.M., Espirito Santo, F. (1996): Climate and climate change. - In: Brandt, C.J., Thornes, J.B. (eds) Mediterranean Desertification and Land Use, John Wiley, Chichester, pp. 43-86.

[61] Parmesan, C., Ryrholm, N., Stefanescu, C., Hill, J.K., Thomas, C.D., Descimon, H., Huntley, B., Kaila, L., Kullberg, J., Tammaru, T., Tennent, J., Thomas, J.A., Warren, M. (1999): Poleward shifts in geographical ranges of butterfly species associated with regional warming. - Nature 399: 578-583.

[62] Phillips, D.L., Dolph, J., Marks, D. (1992): A comparison of geostatistical procedures for spatial analysis of precipitation in mountainous terrain. - Agric. For Meteorol. 58: 119141.

[63] Piovesan, G., Biondi, F., Di Filippo, A., Alessandrini, A., Mauugeris, M. (2008): Drought-driven growth reduction in old beech (Fagus sylvatica) forests of the central Apennines, Italy. - Global Change Biol 14: 1-17.

[64] Pruski, F.F., Nearing, M.A. (2002): Climate-induced changes in erosion during the 21st century for eight U.S. locations. - Water Resour Res 38(12): 1298.

[65] Quintana Seguí, P., Ribes, A., Martin, E., Habets, F., Boé, J. (2010): Comparison of three downscaling methods in simulating the impact of climate change on the hydrology of Mediterranean basins. - J. Hydrol. 383: 111-124.

[66] Rivas Martinez, S. (1993): Bases para una nueva clasificaciòn bioclimatica de la tierra. Folia Bot Matrit 10: 1-23.

[67] Rivas Martinez, S. (1996): Clasificaciòn Bioclimatica de la Tierra. - Folia Bot Matrit 16: 1-29.

[68] Rivas Martinez, S., Loidi Arregui, J. (1999): Bioclimatology of the Iberian peninsula. Itinera Geobot 13: 41-47.

[69] Sabatè, S., Garcia, C.A., Sànchez, A. (2002): Likely effects of climate change on growth of Quercus ilex, Pinus halepensis, Pinus pinaster, Pinus sylvestris and Fagus sylvatica forests in the Mediterranean region. - Forest Ecology and Management 5906: 1-15.

[70] Salvati, L., Petitta, M., Ceccarelli, T., Perini, L., Di Battista, F., Venezian Scarascia, M.E. (2008): Italy's renewable water resources as estimated on the basis of the monthly water balance. - Irrig. Drain 56: 1-11.

[71] Shafer, S.L., Bartlein, P.J., Thompson, R.S. (2001): Potential changes in the distributions of western North America tree and shrub taxa under future climate scenarios. Ecosystems 4: 200-215. 
[72] Sivakumar, M.V.K. (2007): Interactions between climate and desertification. - Agr. Forest Meteorol. 142: 143-155.

[73] Somot, S., Sevault, F., Déqué, M., Crépon, M. (2008): 21st century climate change scenario for the Mediterranean using a coupled atmosphere-ocean regional climate model. - Global and Planetary Change 63: 112-126.

[74] Spada, F. (1977): Primi lineamenti della vegetazione del comprensorio tolfetano-cerite. Quad. Acc. Naz. Lincei 227: 33-50.

[75] Tabios, G.Q., Salas, J.D. (1985): A comparative analysis of techniques for spatial interpolation of precipitation. - Water Resour Bull 21(3): 365-380.

[76] Tchebakova, N.M., Rehfeldt, G.E., Parfenova, E.I. (2005): Impacts of climate change on the distribution of Larix spp. and Pinus sylvestris and their climatypes in Siberia. Mitig. Adapt. Strat. Glob. Change 11: 861-882.

[77] Téllez-Valdés, O., Dávida-Aranda, P., Lira-Saade, R. (2006): The effects of climate change on the long-term conservation of Fagus grandifolia var. mexicana, an important species of the cloud forest in eastern Mexico. - Biodivers Conserv 15: 1095-1107.

[78] Thomas, C.D., Cameron, A., Green, R.E., Bakkenes, M., Beaumont, L.J., Collingham, Y.C., Erasmus, B.F.N., de Siqueira, M.F., Grainger, A., Hannah, L., Hughes, L., Huntley, B., van Jaarsveld, A.S., Midgley, G.F., Miles, L., Ortega-Huerta, M.A., Townsend Peterson, A., Phillips, O.L., Williams, S.E., (2004): Extinction risk from climate change. - Nature 427: 145-148.

[79] Thuiller, W., Lavorel, S., Araujo, M.B., Sykes, M.T., Prentice, I.C. (2004): Climate change threats to plant diversity in Europe. - PNAS 102(23): 8245-8250.

[80] Tirado, M.C., Clarke, R., Jaykus, L.A., McQuatters-Gollop, A., Frank, J.M. (2010): Climate change and food safety: A review. - Food Res. Int. 43: 1745-1765.

[81] Walther, G.R. (2003): Plants in a warmer world. - Perspect. Plant. Ecol. 6: 169-185.

[82] Williams, J.R., Nearing, M.A., Nicks, A., Skidmore, E., Valentine, C., King, K., Savabi, R. (1996): Using soil erosion models for global change studies. - J. Soil Water Conserv. 51(5): 381-385.

[83] Wimbledon, W.A.P., Andersen, S., Clean, C.J., Cowie, J.W., Erikstad, L., Gongrijp, G.P., Johansson, C.E., Karis, L.O., Suomnen, V. (2000): Geosites - A global comparative site inventory to enable prioritisation for conservation. - Memorie Descrittive della Carta Geologica d'Italia LIV: 45-60. 